\title{
Virtue in Corruption: Privateers, Smugglers, and the Shape of Empire in the Eighteenth-Century Caribbean
}

\author{
Casey Sylvia Schmitt \\ College of William \& Mary - Arts \& Sciences
}

Follow this and additional works at: https://scholarworks.wm.edu/etd

Part of the Caribbean Languages and Societies Commons, and the Latin American History Commons

\section{Recommended Citation}

Schmitt, Casey Sylvia, "Virtue in Corruption: Privateers, Smugglers, and the Shape of Empire in the Eighteenth-Century Caribbean" (2013). Dissertations, Theses, and Masters Projects. Paper 1539626724. https://dx.doi.org/doi:10.21220/s2-v08q-cx92 
Virtue In Corruption: Privateers, Smugglers, and the Shape of Empire in the EighteenthCentury Caribbean

Casey Sylvia Schmitt

Edmonton, Alberta, Canada

Master of Arts, University of Utah, 2010

A Thesis presented to the Graduate Faculty

of the College of William and Mary in Candidacy for the Degree of Master of Arts

Lyon G. Tyler Department of History

The College of William and Mary

May, 2013 


\section{APPROVAL PAGE}

This "Virtue in Corruption: Privateers, Smugglers, and the Shape of Empire in the Eighteenth-Century Caribbean" is submitted in partial fulfillment of the requirements for the degree of

\section{Master of Arts}
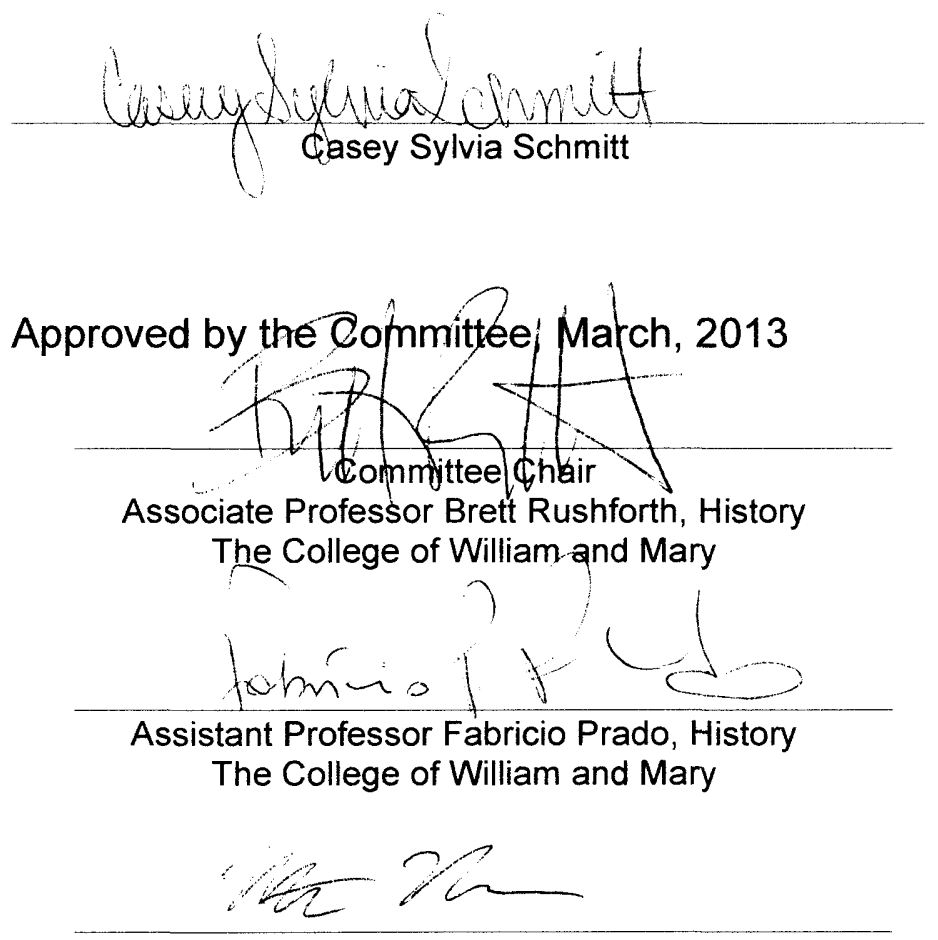

Assistant Professor Matthew Mosca, History The College of William and Mary 


\begin{abstract}
The long and lucrative history of smuggling in the early modern era linked New World economies in defiance of imperial mandates. As British merchants gained increased legal and illegal access to Spanish American ports, Bourbon reformers adopted the anachronistic policy of coastal defense via privateering. My work addresses the history of Bourbon-era privateers and their role in the outbreak of the War of Jenkins' Ear. By reading British accounts of the supposed brutality they encountered at the hands of Spanish privateers against a tradition of Caribbean maritime depredations and widespread smuggling, my work illuminates the ways in which these high seas encounters challenged British naval supremacy and demonstrated the changing nature of Bourbon policy in the eighteenth century. Inter-imperial commercial relations between the Spanish and British in the Americas brought together a diverse group of actors who defied the mercantilist ambitions of their respective monarchies. Spanish colonial residents, due to the erratic arrival of the galleon fleet in the eighteenth century, depended upon predominantly Jamaican merchants for the most basic necessities. For their part, Jamaican interlopers used the licit slave trade of the asiento contract in order to flood the Spanish port cities with British manufactured goods, thereby stimulating the economy of their own island. My thesis explores the nature of the contraband trade in an effort to demonstrate its necessity to the commercial survival of various Spanish and British American peripheries.
\end{abstract}




\section{TABLE OF CONTENTS}

Acknowledgements

Dedications

Section 1.Virtue in Corruption 1

Section 2.Interpretation of Illicit Trade in the Caribbean 4

$\begin{array}{ll}\text { Section 3.The Case of Cartagena } & 10\end{array}$

Section 4.Commercial Invasion and the Guarda Costas 15

Section 5.The International Role of the Guarda Costas 23

Section 6. The Royal Navy and the Commercial Proxy War 28

$\begin{array}{ll}\text { Section 7.The Siege of Cartagena } & 41\end{array}$

$\begin{array}{ll}\text { Bibliography } & 47\end{array}$ 


\section{ACKNOWLEDGEMENTS}

This writer wishes to express her appreciation to Professor Brett Rushforth, whose careful editing and probing questions made this thesis better than I thought it could be. I would also like to thank Professor Paul Mapp for being patient through long conversations as I tried to hammer out my argument as well as for his thought-provoking contributions to those conversations. My thanks also go to Professor Fabricio Prado, who pointed me towards the sources that have proven to be invaluable for my argument. I would also like to express my gratitude to Professor Matthew Mosca, who came in to assist with my thesis at the last minute and, despite that, provided careful editing and thoughtful critique.

Finally, I would like to thank all of the participants at my brown bag seminar who pushed me to be more clear in the organization and structure of my thesis. Elena Schneider at the Omihundro Institute has been extremely supportive over the past two years. Professor Karen Wulf, through a research seminar and her participation in my presentations of this work, has pushed me to sharpen my argument. Professor Guillaume Aubert provided valuable editing advice as well as exciting avenues for future investigation. And, finally, I would like to thank my graduate cohort - Cara Elliott, Hannah Bailey, Spencer Wells, and Katie Snyder - for always being willing to read a draft and share a laugh. Graduate school is much easier when one is surrounded by such wonderful people. 
This thesis is dedicated to Ben and Harry whose good humor and unflappable support are my foundation. 


\section{$\underline{\text { Virtue in Corruption }}$}

Anchored near the channel of Bocachica, at the head of the largest amphibious force organized to date, Admiral Edward Vernon opened an intriguing letter. ${ }^{1}$ Smuggled out of Cartagena de Indias' jail by an escaped Turkish prisoner, the encrypted message gave detailed information about the city's defenses gathered by British captives held there since the outbreak of the War of Jenkins' Ear. The captives assured Vernon that, "[t]here is not half the difficulty that doth appear to you" in attacking the city. ${ }^{2}$ Both Vernon and the captives shared the widespread British belief that Spanish Americans' waning loyalty to Madrid made them an easy target. The bustling Caribbean contraband trade carried on by British subjects in Spain's colonies, in the minds of British observers, underscored the tenuous allegiance of Spanish Americans to their crown. A forest of foreign masts crowding the bay of Cartagena throughout the early decades of the eighteenth century further indicated to the British that the Spanish Empire was inept at controlling its subjects. Capitalizing on that perceived bureaucratic incompetence, Vernon's siege of Cartagena was seen as a formality to break open a Spanish American port which, economically at least, was already assumed to be under British control.

As cannon fire echoed through the streets of Cartagena at the beginning of the siege in 1741, Vernon's informers would have eagerly awaited a prompt victory and their release. The Admiral and his invasion force, however, "Gott more blows than Honour" during the ordeal. ${ }^{3}$ Spanish American defenders, the same who the British assumed would defect to their side, killed 643 of the British invaders who attempted to take the

\footnotetext{
' Richard Harding, Amphibious Warfare in the Eighteenth Century: The British Expedition to the West Indies 1740-1742 (Rochester, NY 1991).

2 Petition to Vernon from the English Prisoners in Cartagena (Copy) [April/May 1741] in Ranft, The Vernon Papers, p. 235. (Harding 1991) (Ranft 1958)

${ }^{3}$ Diary of Captain Benjamin Norton, Saturday, June 20, 1741 in (Jameson 1923), ed., Privateering and Piracy in the Colonial Period: Illustrative Documents (New York, NY 1923): 387.
} 
Fort of St. Lazar. ${ }^{4}$ Vernon's inglorious defeat at Cartagena proved to be one of the more embarrassing for the British during the War of Jenkins' Ear. The war itself was fought largely for commercial reasons, sparked by British public outrage at the aggressive seizures of Anglo-American vessels accused of smuggling by Spanish American guarda costas patrolling the Caribbean. ${ }^{5}$ This same pre-war violence between British merchants and guarda costas that brought Vernon to Cartagena in the first place should have dissuaded him from any notion of a painless victory. However, as Vernon would discover too late to salvage his invasion attempt, smuggling in Cartagena provided the city a means of defense rather than the seeds of its supposed disloyalty to the Spanish crown. Blindness to the benefits of contraband and the violent responses of Spanish American corsairs proved disastrous for British officials at Cartagena.

Vernon's invasion attempt was informed by a widespread belief among the British that smuggling and imperial loyalty were mutually exclusive. Observers described the trade through terms like vice, corruption, and degeneracy and historians have followed the language of these sources in condemning Spanish American officials who participated in the trade as self-serving and disloyal. ${ }^{6}$ However, this interpretation does

\footnotetext{
${ }^{4}$ Ranft, The Vernon Papers, p. 17.

${ }^{5}$ Guarda Costas were privateering vessels outfitted in Spanish American port cities to combat the widespread contraband trade.

${ }^{6}$ Some of the eighteenth-century sources condemning Spanish American officials' participation in contraband trade as corruption are: José del Campillo y Cossío, Nuevo sistema de gobierno económica para la américa (Universidad de los Andes, Merida, Venezuela, 1971, 1789); Jorge Juan, Antonio de Ulloa, and David Barry, Noticias Secretas De America (Londres: en la imprenta de R. Taylor, 1826); and Antonio Julián. S.J., La Perla de la América, Provincia de Santa Marta (Edición facsimilar) (Academia Colombiana de Historia, Bogotá, 1980, 1787). For some examples of contemporary histories that repeat this kind of vocabulary, see: Stanley J. Stein and Barbara H. Stein, Silver, Trade, and War: Spain and America in the Making of Early Modern Europe (Baltimore: Johns Hopkins University Press. 2000): Héctor R. Feliciano Ramos, El Contrabando inglés en el Caribe y el Golfo de México, 1748-1778 (Sevilla, 1990); J.H. Elliott, Empires of the Atlantic World: Britain and Spain in America, 1492-1830 (Yale University Press, 2006); Lance Grahn, The Political Economy of Smuggling: Regional Economies in Early Bourbon New Granada (Westview Press, Oxford, 1997); and Colin Palmer, Human Cargoes: The British Slave Trade to Spanish America, 1700-1739 (University of Illinois Press, 1981).
} 
not sufficiently explain the repulsion of Vernon's invasion or the daily violence surrounding the contraband trade. (This article will argue that) The situation that Vernon encountered on the ground in Cartagena reflected the fact that certain kinds of contraband proved essential to the functioning of Spanish American economies and received the tacit approval of metropolitan officials. The War of Jenkins' Ear, although waged between Britain and Spain over issues related to illicit trade, could not have been fought in peripheral regions like Cartagena without those illegal supply chains. Further, emphasis on the corrupting influence of contraband trade is too simplistic. Cartagena's political economy functioned in a vicious cycle: Jamaican interlopers supplied the Spanish guarda costa vessels that perpetrated the violence against British shipping that brought the two crowns to war, thereby increasing Cartagena's demand for illicit goods. Contraband trade was not peripheral to this world or, as one scholar describes smuggling, "outside both the ideological and the pragmatic reach of imperial officials." "The function of contraband goods in the build-up to Vernon's siege of Cartagena illuminates the internal logic of smuggling that provided for the city's protection while simultaneously creating the need for more defense.

Vernon's miscalculation of the strength and flexibility of Spain's American empire proved costly. Yet, focusing just on Vernon's failure at Cartagena ignores his own complicated relationship with smuggling. Following a tradition of illicit trade in the British Royal Navy, Vernon carried contraband goods with as much ease as he carried out official orders and, often, doing one required the other. ${ }^{8}$ Just as Vernon relied on

\footnotetext{
${ }^{7}$ Cathy Matson, "Imperial Political Economy: An Ideological Debate and Shifting Practices," in William and Mary Quarterly, 3d ser., 69, no. 1 (Jan. 2012): 40.

${ }^{x}$ See: N.A.M. Rodger, The Command of the Ocean: A Naval History of Britain, 1649-1815 (W.W. Norton \& Company, New York 2004):234-5.
} 
smuggling to supply his crew for attacking Spanish territories, Spanish American officials in Cartagena also made pragmatic choices in the face of constricted options. Assigned the unenviable task of defending the port city from British commercial invasion despite a lack of supplies from legal channels, port official Gabriel de Mendinueta engaged in illicit trade in order to equip the naval vessels charged with harassing British smugglers. Instead of contradicting Spain's imperial goals, Mendinueta and the guarda costas served the global interests of metropolitan planners like José Patiño. The choices made by men like Vernon and Mendinueta illuminate the tensions and desires in Cartagena, Madrid, Kingston, and London that created the cycles of contraband and violence that erupted into the War of Jenkins' Ear and continued long after.

\section{Interpretations of Illicit Trade in the Caribbean}

In imperial communications throughout the seventeenth and eighteenth centuries, British and Spanish colonial officials interpreted the rampant contraband trade carried on in Spain's American dominions as a sign of locals' greed. Many in the Spanish Empire saw contraband trade as a structural problem that stemmed in large part from the corruption of colonial authorities in American port cities. Two officials described the "vicious illicit commerce," around Cartagena as a "deeply embedded system," that flourished due to the "the misguided behavior of those who govern," who they saw as "openly greedy and self-seeking at the expense of others." ${ }^{\text {9 }}$ For others, the sheer size of the problem made finding a solution seem insurmountable. According to a viceroy of New Granada in the 1740 s, the crown could not "completely castigate this pernicious trade" without "five hundred thousand men to guard those coasts and to guard the guards

\footnotetext{
${ }^{9}$ Ibid., p.242.
} 
after them," who "succumb[ed] to bribery." 10 General opinion seemed to discount the idea that more soldiers could change the climate of corruption in Cartagena. Foreign merchants were described as unloading goods "at whatever time of the day or night, and go through with them to the streets of this city" with total impunity. " This description matched the words of the British Rear Admiral Charles Stewart in 1731 when he wrote that, "Villainy is inherent to this climate."12 Antonio Julián, a priest who resided in New Granada, foresaw the fatal weakening of the empire if steps were not taken to address the smuggling trade. In Julián's words "if the foreigners carry away the blood of the New Kingdom, it remains underfed and the Monarchy loses little by little its vigor and substance." 13 Imperial advisors also warned that contraband trade weakened the state's fiscal health because the goods consumed in the American colonies were of foreign origin. According to a close minister of Philip V, "We have the most abundant markets in the world without leaving the dominions of the King; but they serve us little, as twenty percent of what is consumed in the Indies is a product of Spain." ${ }^{14}$ Spanish imperial agents on both sides of the Atlantic spoke in unison when they disparaged the rampant contraband trade with foreigners that occurred in the king's American territories. And, in each case, the loudest chorus of voices was reserved for vilifying the local officials who allowed the trade to continue.

\footnotetext{
${ }^{10}$ Gabriel Giraldo Jaramillo, Relaciones de Mando de los Virreves de la Nueva Granada (Publicaciones del Banco de la República, Bogotá, Colombia 1954): 42. (Translation is my own.)

${ }^{11}$ Archivo General de Indias, Santa Fe 1233. Letter from Juan Pablo de Ibarra to the King, August 1727 translation is my own

${ }^{12}$ Quoted in, N.A.M. Rodger, The Command of the Ocean: A Naval History of Britain, 1649-1815 (W.W. Norton \& Company, New York, NY 2004): 235.

${ }^{13}$ Antonio Julián, S.J. La Perla de la América, Provincia de Santa Marta (Edición facsimilar) (Academia Colombiana de Historia, Bogotá, 1980), p.256. (Translation is my own.)

${ }^{14}$ José del Campillo y Cossío, Nuevo sistema de gobierno economic para la américa (Universidad de los Andes, Merida, Venezuela, 1971): 70.
} 
Many observers outside of the Spanish empire saw the widespread illicit trade in the American colonies as symptomatic of Spain's declining power, a decline that would lead to Spain's loss of its American revenue. Even French imperial circles discussed the apparent weakness of Spain's control over its American colonies, as when Michel-Jean Amelot lamented that "The riches of Peru and Mexico. . .are almost lost to Spain," in a correspondence with Louis XIV. ${ }^{15}$ The lawless character in the Americas seemed to indicate to Amelot that Spain's American subjects were on the verge of violently shaking off imperial rule. Amelot wrote that, "Avarice and pillage are unpunished, fortresses and garrisons are neglected; all things seem to portend a fatal revolution." 16 Spanish America's apparent moral laxity with regard to the contraband trade played into the pervasive myth of Spain's ailing imperial health by the eighteenth century. ${ }^{17}$ Throughout official British correspondence and in newspapers bellicose rhetoric regarding Spanish weakness was oft-repeated. Many pointed to the ease with which a war between the two would tip in Britain's favor, stating that, "If the Spaniards should bring us to the necessity of getting upon a War. . it will be carry'd on with such Force and Vigour, as will soon reduce them to Reason." 18 The supposed prevalence of venal and corrupt officials in Spanish America indicated to Spain's rivals that the empire was little more than a house of cards, ready to tumble with the slightest disturbance. Spain's failure to supply its colonies also added weight to the assumption outside of the Iberian Peninsula that Spanish Americans would flock to a foreign banner if given the opportunity.

\footnotetext{
15 John Lynch, Bourbon Spain: 1700-1808 (Basil Blackwell, Cambridge, Mass. 1989): 59.

${ }^{16}$ Ibid., p. 59.

${ }^{17}$ For a discussion of this myth, see: Frank Jay Moreno, "The Spanish Colonial System: A Functional Approach," Western Political Quarterly, Vol. 20, N. 2, (Jun. 1967), pp. 308-320; Alejandro Cañeque, The King's Living Image: The Culture and Politics of Viceregal Power in Colonial Mexico (Routledge, New York, 2004); and Paul W. Mapp, The Elusive West and the Contest for Empire, 1713-1763 (Chapel Hill, NC 2011).

${ }^{18}$ American Weekly Mercury, August 7, 1729, issue 500, p. 3.
} 
While Spanish commentators seemingly condemned local officials and worried about the future of their empire, their British counterparts praised the possibilities for wealth generated by the contraband trade. The majority of British interlopers in the Caribbean called Jamaica home, and their proximity to the Spanish Main provided a boon to the island's economy. As Jamaican resident Richard Harley explained, "[t]he Trade with the Spaniards from Jamaica (tho' Collusive) has been very considerable," and that "there has been received from them in Gold and Silver and the Produce of New Spain, $200,000 l$. or 250,000 l. Yearly." 19 A more conservative estimate than Harley's may have been closer to the truth, such as that proposed by Jamaican Governor Nicholas Lawes, who stated that " $[\mathrm{t}]$ he private trade use to bring into England between 2 and $£ 3,000$ a year in ps. $8 / 8$ silver, and gold." ${ }^{20}$ Regardless of the figures, the island of Jamaica was an important staging ground for the commercial invasion of Spanish America. According to an early governor of Jamaica, possession of the island by the British effectively meant that they would "become the masters of the mines of Mexico and Peru" by syphoning off precious metals through contraband. ${ }^{21}$ In fact, by the mid-1730s, some in Parliament thought that the contraband trade between Jamaica and the Spanish Main was so well established that the trade's legality might have been hazy to those on the ground. In one debate, Sir William Yonge reasoned that Jamaicans "might be concerned in a contraband trade in America, without themselves knowing that it was contraband." For Yonge and other members of Parliament, smuggling had become so common for British American merchants that "many among them think they have as good a right to trade with the

\footnotetext{
${ }^{19}$ Elizabeth Donnan, Documents Illustrative of the History of the Slave Trade to America (Carnegie Institute of Washington, 1931), p.151.

${ }^{20}$ CSP, no. 272 (1717-18): 175.

${ }^{21}$ Great Britain, Public Record Office, Calendar of State Papers, Colonial no. 97 (1696-1697): 179 (hereafter cited as CSP).
} 
Spanish as with our own settlements. ${ }^{, 22}$ For British observers, Spain seemed incapable of a vigorous defense of its commercial interests in the Americas and British American interlopers took advantage of that fact, aided in large measure by the participation of local Spanish American officials.

Echoing the arguments of eighteenth-century Spanish imperial agents and their British counterparts, much of the historiography of Caribbean smuggling assigns blame to local Spanish American officials. In the words of one scholar, the port of Cartagena "was a hotbed of illegal activity." 23 The large-scale smuggling witnessed by eighteenthcentury observers depended on, as argued by another scholar, the "collaboration of the royal officials" in Spanish America who were "frequently denounced. . for venality and corruption. ${ }^{24}$ Bribery serves as an explanation for some as to how so much contraband moved through Spanish American ports. According to historian J.H. Elliott, colonial officials like Mendinueta "would wink at this illicit trade once their palms had been greased. ${ }^{25}$ Despite the attention given to smuggling, however, contraband trade remains seen as something carried on in the periphery and beyond the ability of imperial planners to prevent or curtail. ${ }^{26}$ Overall, this picture of the political economy of smuggling points to the easy illicit relationships carried on between subjects of different empires out of sight of their metropolitan superiors. In this system, the vast expanse of the Atlantic Ocean prevented imperial officials from reigning in their perfidious subjects who

\footnotetext{
${ }^{22}$ A Collection of the Parliamentary Debates in England, from the year M,DD,LX VIII To the present time, vol. 16 (London, 1735): 53.

${ }^{23}$ Lance Grahn, The Political Economy of Smuggling: Regional Economies in Early Bourbon New Granada (Westview Press, Oxford, 1997): 5.

${ }^{24}$ Colin Palmer, Human Cargoes: The British Slave Trade to Spanish America, 1700-1739 (University of Illinois Press, 1981): 88.

${ }^{25}$ J. H. Elliott, Empires of the Atlantic World: Britain and Spain in America, 1492-1830 (Yale University Press, New Haven, Conn., 2006): 224.

${ }^{26}$ Cathy Matson, "Imperial Political Economy: An Ideological Debate and Shifting Practices," in William and Mary Quarterly, 3d ser.. 69, no. 1 (Jan. 2012): 40.
} 
appeared to be more comfortable economic bedfellows with each other than with their own merchants. In the dominant historiographic narrative, corruption as a result of disloyalty served as the driving force in the Caribbean economy, resulting in the image of a weak Spanish crown unable to control or protect its American possessions.

Corruption in eighteenth-century Spanish America, however, must be understood in light of the proscriptive nature of Iberian law. In fact, in much of the early modern world, law and practice did not match up, but such discrepancies were not indicative of rampant corruption. As historian Frank Jay Moreno lucidly explains, Spanish law frequently outlined humanistic and idealistic contours of proper behavior with the tacit understanding that such laws would, of necessity, be broken. ${ }^{27}$ Furthermore, the issue of corruption becomes difficult to define in the Spanish American world, where the structure and dissemination of authority depended on ties of patronage that connected the king to his subjects across the ocean. As historian Alejandro Cañeque argues, the Spanish imperial system was one of an "economy of favor" in which agents of the empire routinely used client-patron incentives, like bribery, to cement allegiance to a distant king. ${ }^{28}$ In this sense, corruption occurred only when agents of the Spanish king acted against the king's interests in pursuit of their own enrichment. It was, in fact, this "network of personal relations," according to historian Zacarías Moutoukias, which "served to make the administrative structure more flexible," and capable of assimilating political and economic challenges with a proscriptive and idealistic legal culture. ${ }^{29}$

\footnotetext{
${ }^{27}$ Frank Jay Moreno, "The Spanish Colonial System: A Functional Approach," Western Political Quarterly, Vol.s 20, No. 2, Part 1 (Jun., 1967) pp. 308-320.

${ }_{28}$ Alejandro Cañeque, The King's Living Image: The Culture and Politics of Viceregal Power in Colonial Mexico (Routledge: New York, 2004): 174.

${ }^{29}$ Zacarías Moutoukias, "Power, Corruption, and Commerce: The Making of Local Administrative Structure in Seventeenth-Century Buenos Aires," Hispanic American Historical Review, Vol. 68, No. 4, (Nov., 1988), pp. 771-801: 776.
} 
"Corruption" in Spanish America, therefore, must be interpreted in accordance with colonial reality on the ground rather than through British misinterpretations or the proscriptive Spanish American legal culture.

\section{The Case of Cartagena}

Situated on the tropical lowlands of the Spanish Main, Cartagena de Indias overlooked one of the most famed bays in the Americas. Named for the equally as impressive harbor-city of Cartagena, Spain, Cartagena de Indias was constructed on a sandy island engulfed to its north by a wide bay and hemmed in on the south by a narrow slit of water. The bay of Cartagena was especially well-suited for harboring ships, as Spanish naval officials described, it "extends two leagues and a half from north to south; has a sufficient depth of water and good anchorage; and [is] so smooth, that the ships are no more agitated than on a river." 30 Situated on the brim of the Spanish Caribbean and within short sailing time to Porto Bello, Cartagena de Indias became the cornerstone of Spain's transatlantic trade with the southern territories of Peru. The Spanish galleons dispatched for the trade fair at Porto Bello weighed anchor first at Cartagena and waited to receive word that the treasure ships of Peru had reached Panama. Once the announcement arrived that the silver-laden ships had landed, the Spanish galleons would leave their anchorage at Cartagena and sail to Porto Bello to start off the annual trade fair. At the conclusion of that fair, if everything went to imperial specifications, the fleet would once again return to Cartagena before making the voyage back to Spain. ${ }^{31}$ In this

\footnotetext{
30) Jorge Juan and Antonio de Ulloa, A Voyage to South America (London, 1772): 26.

${ }^{31}$ Museo Naval de Madrid, No. inventario: 5279, Signatura: 4388, “Proyecto Para Galeones, Y Flotas, de el Peru, Y Nueva España, Y Para Navios de Registro, Y Avisos Que Navegaron A Ambos Reynos”; Stein and Stein, Silver, Trade, and War, pp. 100-150.
} 
imperial scheme Cartagena de Indias proved important not for what it contributed to the trade fair but for the safe landing and refitting it provided the flota on both ends of its voyage.

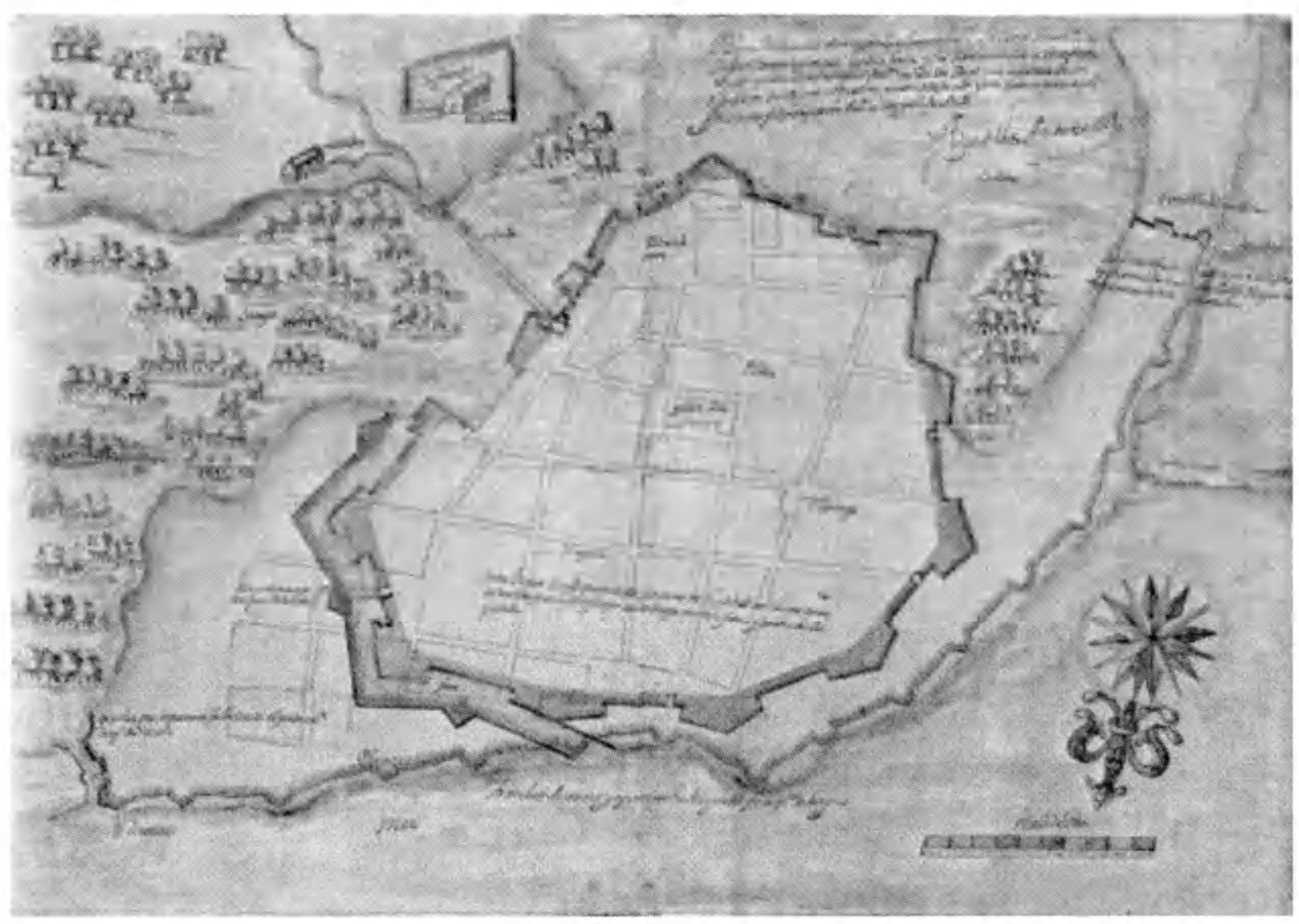

Cartagena de Indias, AGI 1594

The sheer value of trade which anchored at Cartagena de Indias kept the port city in the forefront of Spain's strategic calculations in the Caribbean. One scholar estimates that during the middle decades of the eighteenth century, nearly $1,800,000$ pesos of silver a year arrived at the port of Cartagena before being sailed back to Cadiz. ${ }^{32}$ That silver from the mines of Potosí and the interior supplied the Spanish crown with the bullion it

\footnotetext{
${ }^{32}$ Lance Grahn. The Political Economy of Smuggling: Regional Economies in Early Bourbon New Granada (Westview Press, Oxford, 1997), p.18.
} 
needed to advance its European objectives in a century of near constant warfare. The successful seizure of the 1628 treasure fleet off the coast of Cuba by the Dutch privateer Piet Heyn, a bounty worth roughly 4.8 million silver pesos, justified the Spanish crown's single-minded focus on the treasure fleet in the Caribbean. ${ }^{33}$ Possession of a port described at the time as admitting "only one ship at a time, and even she must be obliged to keep close to shore," guaranteed that in at least one leg of the silver's transatlantic voyage, metropolitan planners could be assured of its safety. ${ }^{34}$

The amount silver that passed through Cartagena de Indias each year inspired the envy of Spain's imperial rivals. Cartagena suffered successful sacks by Francis Drake in 1586, Henry Morgan in 1668, and the French baron of Pointis, Bernard Louis Desjean in 1697. ${ }^{35}$ Foreign aggression against the city meant that by the mid-eighteenth century providing for the city's security became a major concern. According to official Spanish sources, "[t]he garrison in times of peace consist[ed] of ten companies of regulars, each containing, officers included, 77 men; besides several companies of militia." ${ }^{\text {36 }}$ The primary responsibility of Cartagena's imperial officials was to prevent the 1628 Cuban disaster from reoccurring and guarantee safe anchorage to the galleon fleet. The territorial toeholds gained by Spain's rivals in the Caribbean were initially intended as staging grounds for attacks on Spain's lucrative trade with its American colonies. Surrounded by aggressive rivals at Jamaica, Curaçao, and Martinique, Cartagena central to the safe passage of the galleon fleet.

\footnotetext{
${ }^{33}$ Kris E. Lane, Pillaging the Empire: Piracy in the Americas: 1500-1750. (M.E. Sharpe, Inc. 1998), pp. 69-71.

${ }^{34}$ Jorge Juan and Antonio de Ulloa, A Voyage to South America (London, 1772): 26.

${ }^{35}$ Francisco Javier Membrillo Becerra, La Batalla de Cartagena de Indias (Publidisa, Madrid, Spain 2011): 24.

36 Juan and Ulloa, A Vovage to South America, p. 23.
} 
Despite being well-defended and strategically important, Cartagena de Indias suffered along with the majority of Spanish America in the eighteenth-century from a lack of legal Spanish trade goods, leaving residents with few legal options for acquiring merchandise. As the president of the Audiencia de Santa Fe explained to the king, "the pitiful situation," in New Granada was that "the land has so many riches and abundance [yet] where almost all of the inhabitants and citizens are beggars. ${ }^{, 37}$ Despite the tremendous wealth that passed through the port of Cartagena, the region itself remained trade-poor. Periods of time between flotas produced hardships for the residents and soldiers alike in Cartagena. According to visiting officers of the Spanish navy, the lengths of time without trade fairs "the inhabitants of Cartagena call tiempo muerto, the dead time; for, with regard to the trade carried on with the other governments [of the Spanish empire], it is not worth notice." 38 Through the stifling heat of Caribbean summers or entire years in which the flota never came, metropolitan planners expected local officials to keep the port of Cartagena safe and clear but provided little by way of much-needed supplies.

The economic strain of Cartagena, moreover, was not particular to the eighteenth century. Even during the economic boom of the sixteenth century, Cartagena relied on outside funds for the maintenance of its port and garrisons. The placer mining which produced a flush of gold at Cartagena's founding faltered in the later decades of the seventeenth century. What little gold enslaved Africans coaxed out of the region's tropical streambeds during the course of a century proved insufficient for the construction

\footnotetext{
${ }^{37}$ Gabriel Giraldo Jaramillo, Relaciones de Mando de los Virreves de la Nueva Granada (Publicaciones del Banco de la República, Bogotá, Colombia 1954): 23. (Translation is my own.)

${ }^{38}$ Juan and Ulloa, A Voyage to South America, p. 83.
} 
and maintenance of Cartagena's military installations. ${ }^{39}$ Imperial planners used the situado, or treasury funds, from wealthier areas of Spanish America in order to pay for the defense of Cartagena's port. Drawing the majority of its situado from Quito, Cartagena scrapped together enough wealth, as reported by Spanish officials, "for keeping up the fortifications, furnishing the artillery, and other expences, necessary for the defence of the place and its forts. ${ }^{, 40}$ Spain diverted resources to the defense of Cartagena due to the port's strategic importance in the imperial trade system.

Despite the primacy of the city's port, Cartagena's hinterlands proved incapable of supporting the Tierra Firme fleets. Cartagena dealt with a very basic problem as a tropical outpost - it was too hot to cultivate European staples. As one moves inland from New Granada's hot and humid coastline, increased elevation and decreased temperatures yield to a landscape more favorable to wheat cultivation. Despite the relative proximity between the port and the highland city of Santa Fe de Bogotá, however, wheat cost 2,000 percent more in Cartagena than in the highlands where it was grown. ${ }^{41}$ The voyage from the tierra fría in the spine of the Andes to the tropical lowlands took four arduous months, during which time the wheat generally went bad if it arrived at all. Without a reliable domestic supply or legal imports of wheat, officials in Cartagena relied on foreign supplies. The proximity of Jamaica, moreover, plugged Cartagena into the provisions trade circuits of British North America. ${ }^{42}$

\footnotetext{
39) Anthony McFarlane. Colombia Before Independence: Economy, Society, and Politics Under Bourbon Rule (Cambridge University Press, 1993), p.8.

${ }^{40)}$ Juan and Ulloa, A Vovage to South America, p. 84.

${ }^{+1}$ John R. Fisher, Allan J. Kuethe, and Anthony McFarlane, eds. Reform and Insurrection in Bourbon New Granada and Peru (Baton Rouge, Louisiana 1990): 140.

${ }^{+2}$ Colin Palmer, Human Cargoes: The British Slave Trade to Spanish America, 1700-1739 (University of Illinois Press, 1981), p.61.
} 


\section{Commercial Invasion and the Guarda costas}

At the conclusion of the War of the Spanish Succession, Britain gained the exclusive right to carry slaves to Spain's American colonies, known as the asiento contract. Starting in 1713, Queen Anne granted the privilege of conducting that trade to the newly formed South Sea Company. The island of Jamaica, positioned in the center of the Spanish Caribbean, was a suitable choice as a refreshment station for the South Sea Company's trans-Atlantic slaving vessels. Initially both Barbados and Jamaica were used, by the mid-1720s, Jamaica eclipsed Barbados in importance due to the resources of the island and the volume of trade carried on there. ${ }^{43}$ The abundance of cattle and produce in the early decades of the eighteenth century, before more land on the island was dedicated to the production of sugar, meant that the factories there were well-stocked. ${ }^{44}$ South Sea Company agents recuperated and quarantined the enslaved Africans at Kingston after the horrors of the Middle Passage in an attempt to make them appear healthy before being shipped to their final destinations for sale.

Jamaica's location appealed to more than just legal representatives of the South Sea Company and the convergence of trade goods intended for Spanish America on the island provided ample opportunity for smugglers. Private smugglers and Company ships encountered stiff competition for Spanish American trade among Britain's Royal Navy. Upon taking his post as governor, Nicholas Lawes was appalled by the conduct of the Royal Navy stationed at Jamaica. Despite the nearly constant dangers of piracy and

\footnotetext{
${ }^{43}$ Ibid., p.59.

${ }^{44}$ Factories, in this sense, refer to the outposts established throughout the Atlantic World by slave trading companies where slaves were housed and fed after the Middle Passage and before their sale. The merchants who resided in these posts were referred to as factors and will be referred to as such.
} 
harassment by Spanish privateers, Lawes found the British ships assigned to the island absent. The very Navy vessels upon which Jamaicans depended for their security, the Winchelsea, the Ludlow Castle, and the Diamond, had sailed down to the Spanish Main days before, laden with contraband goods. Lawes' rude awakening to the operations of the British Royal Navy in the Caribbean would not be the last of his short tenure, nor would the Navy's dedication to smuggling ebb in the coming years. ${ }^{45}$ The participation of the Royal Navy in trade that Spanish imperial agents considered illicit indicates an organized and aggressive commercial pressure on the part of the British. This pressure is not adequately described by terms like "interloper" and "smuggler," which denote a small-scale illegality rather than an institutionalized attempt to break open Spanish American ports on the part of the British Navy. The Royal Navy's engagement in the contraband trade also escalated opportunities for violence between the two crowns in the waters of the Caribbean.

Spanish imperial planners confronted this veritable commercial invasion of the crown's American possessions without a strong naval presence of their own. As a result, Spain issued corsair patents to captains willing to defend Spanish American waters by searching and seizing smuggling vessels. Stemming from precedent set in the seventeenth century, Spain awarded successful seizures with a portion of the prize money to be adjudicated in local courts. ${ }^{46}$ Commercial incentives on both sides created flashpoints of violence across the Caribbean as guarda costas and British merchantmen encountered one another on the high seas. Most of these meetings met with "the usual Compliments of

\footnotetext{
${ }^{45}$ Great Britain, Public Records Office, Calendar of State Papers, Colonial (1717-1718): 271 (hereafter cited as CSP).

${ }^{46}$ Luis Navarro García, Historia General de España y América: Tomo XI-I, Segunda Edición (Ediciones Rialp, S.A., Madrid, Spain 1981):34.
} 
hanging, burning Matches between their Fingers, \&c.” ${ }^{47}$ Spanish privateers were accused in the British American press of excessive violence, such as when a Boston merchant sloop was taken and, "in cold blood [they] cut the Master and all his Men to pieces, saving only the Cabbin-Boy." 48 The spread of guarda costas throughout Spanish American ports turned British contraband trading into a dangerous venture while the increased presence of ships of the British Royal Navy raised the stakes for Spanish privateers as well.

In this environment of simmering conflict, a British sloop weighed anchor in the bay of Cartagena de Indias in February of 1729. The sloop had sailed south from Jamaica, choosing to land at the well-fortified port instead of any other point along the 1,500 leagues of relatively undefended coastline running from Caracas to Lima. ${ }^{49}$ The British vessel would have passed through the channel of Boca Chica, that straight so narrow that only one ship could sail through at a time. On the vessels' left stood the fort of San Luis de Boca Chica, a fortification at the far end of Tierra Bomba, whose cannons sat poised for action as the Jamaican vessel sailed past. ${ }^{50}$ Once at the port, the Jamaican interloper unloaded two hundred barrels of flour in clear view of Mendinueta and other port officials. ${ }^{51}$ As with so many cases of foreign merchants unloading cargo in Spanish American port cities, this Jamaican interloper presumably paid a handsome bribe and profited from Mendinueta's venality.

\footnotetext{
47 South Carolina Gazette, January 29, 1731-2, no. 4.

${ }^{48}$ The Boston News-Letter, March 5, 1730, issue 166, p. 2.

49) Jorge Juan and Antonio de Ulloa. Discourse and Political Reflections on the Kingdoms of Peru (University of Oklahoma Press, 1978), p.241.

${ }^{50)}$ For a description of the fortifications of Cartagena, see: Jorge Juan and Antonio de Ulloa, A Vovage to South America (London, 1772): pp. 26-30.

${ }^{51}$ Archivo General de Indias, Santa Fe 1093, Don Gabriel de Mendinueta, Puerto de Cartagena 16 de febrero, 1729.
} 
And yet, Mendinueta addressed a letter to Phillip V in order to explain the entrance of the Jamaican's contraband flour. While he remains silent as to whether or not his "palms were greased," he makes clear that the barrels were intended for the Spanish American seamen who would risk their lives seeking out prizes and defending the crown's commercial interests in the circum-Caribbean. Perhaps Mendineuta's letter serves as a cover, artifice for his own involvement in a lucrative smuggling ring which supplied the residents of Cartagena rather than its hard-working naval crews. Such an accusation may be true and, as is common when observing illegal activity from a remove of several centuries, completely unverifiable. Mendinueta's own promotion to captain of New Granada's guarda costa squadron that same year indicates that at least someone considered his performance as port official commendable. ${ }^{52}$ Further, at no point were the guarda costas themselves a mere artifice for illegal activity, as more and more cases of violent maritime encounters in the Caribbean make clear.

The case of Mendinueta illustrates the countervailing pressures encountered by subjects of the Spanish crown in the Caribbean and the pragmatism required to deal with those pressures. While letters of patent for corsairs alleviated Spain's pressing need for increased naval strength for a time, Spanish American corsairs in ports like Cartagena still required foodstuffs and naval stores to operate. In the near-century between the 1670 s and the 1760 s only ten galleon fleets passed through the port of Cartagena - six between 1675 and $1700^{53}$ and four between 1713 until $1763 .^{54}$ Many of the intended voyages were prevented from embarking from Sevilla, and later Cadiz, due to the almost

\footnotetext{
52 Grahn, The Political Economy of Smuggling, p. 156.

53 Anthony McFarlane. Colombia Before Independence: Economy, Society, and Politics Under Bourbon Rule (Cambridge University Press, 1993), p.22.

${ }^{54}$ Lance Grahn. The Political Economy of Smuggling: Regional Economies in Early Bourbon New Granada (Westview Press, Oxford, 1997), p.20.
} 
continuous state of war on the continent and in the sea lanes of the Caribbean. Still others were waylaid in Spanish American ports, unable to sell their merchandise due to the prevalence of contraband goods which flooded the otherwise empty markets. As a result port officials like Mendinueta used illicit trade in order to equip guarda costas. ${ }^{55}$ The presence of armed Royal Navy ships near Spanish American ports meant that the safety of the port depended on equipping Spanish American corsairs through any means necessary.

The calculation of supplying the guarda costas over prosecuting the contraband trade proved as much economic as it was strategic. Contraband trade may have challenged Spain's claim to monopoly privileges over its American possessions, but such challenges mattered little when compared to the wealth brought into Spain through the galleon fleet. While Jamaican observers estimated the contraband trade with the Spanish Main yielded between $£ 200,000$ to $£ 250,000$ a year, the Spanish crown remained concerned with the much larger sums of Peruvian silver brought to the Iberian Peninsula each year. ${ }^{56}$ Assuming a consistent value of $£ 196,000$ as the value of Spanish American goods earned through illicit trade and multiplying that value by the thirty year period in which Britain held the asiento contract, Britain earned roughly 5.9 million pounds. ${ }^{57}$ On the other hand, even estimating that the galleon fleet only completed a successful voyage eight times in the same period with an average of $1,800,000$ pesos onboard, Spain earned

\footnotetext{
${ }^{55}$ Nor was Mendinueta's case extraordinary in Spanish America, as historian Zacarías Moutoukias' work on the role of illicit trade in the supplying of Buenos Aires' garrisons with monetary loans and supplies in the seventeenth-century makes clear. According to Moutoukias, in a comment that applies equally as well to Cartagena, "corruption was born out of the conditions in which the system was erected," in, Moutoukias, "Power, Corruption, and Commerce," p. 799.

${ }^{56}$ Elizabeth Donnan, Documents Illustrative of the History of the Slave Trade to America (Carnegie Institute of Washington, 1931), p.151.

${ }^{57}$ For the $£ 196.000$ value for 1715, see: Curtis P. Nettels, The Money Supply of the American Colonies before 1720 (Clifton, New Jersey 1973): 40.
} 
roughly 14.4 million pesos through its transatlantic trade. ${ }^{58}$ While the erratic arrival of the galleons to Cartagena during the eighteenth century proved insufficient to supply the port city, the value of those return shipments of silver far outweighed the value of the contraband trade. From the perspective of Spain's imperial economy, therefore, Mendinueta's primary responsibility lay with protecting the galleons rather than limiting foreign imports.

Furthermore, Mendinueta could not bar entrance to some foreign interlopers while admitting only those needed to supply the garrison and the guarda costas. According to Spanish naval officials, if Mendinueta chose to selectively prosecute some interlopers, then, "no other ship would enter their port." While these same officials assumed that the lack of ships entering the port would upset local officials because it would mean the loss of their source of illicit income, perhaps there is a less cynical way of interpreting the apparent lack of action against foreign interlopers at Cartagena. If confiscation of one foreign vessel would frighten the others away from the port, Mendinueta would sacrifice his ability to provide for Cartagena's coast guard defense by vigorously prosecuting the contraband trade. The loss of foreign trade would have left the garrisons of Cartagena without a sufficient supply of basic staples, further jeopardizing Mendinueta's ability to defend the port. Within the framework of the larger Spanish political economy, the seizure of foreign vessels at the port of Cartagena would have caused more harm than benefit. $^{60}$

\footnotetext{
${ }^{58}$ Lance Grahn. The Political Economy of Smuggling: Regional Economies in Early Bourbon New Granada (Westview Press, Oxford, 1997), p.18.

${ }^{59}$ Juan and Ulloa, Discourse and Political Reflections, p. 50.

${ }^{60}$ The role of contraband trade and its persecution on the ground in Cartagena affords another promising route of inquiry not taken in the current study. While personal profit motivated merchants to outfit guarda costas and competition between different political factions in Cartagena played a role in harassing British
} 
While the value of the fleets which passed through Cartagena proved exceptional, Mendinueta was not the only Spanish American officials who used illicit supply chains to defend Spanish possessions. According to historian Joyce Elizabeth Harmon, Manuel de Montiano, the governor of Florida, faced similar circumstances in the year before the outbreak of the War of Jenkins' Ear. In a letter sent to the governor of Cuba, Juan Francisco de Güemes y Horcasitas, Montiano explained his own engagement in contraband trade with British North America. According to Montiano, a shipment of New York flour arrived at St. Augustine because he worried that the impending conflict and the increased violence in the waters of the Caribbean would cut off his peripheral port. ${ }^{61}$ For that reason, Montiano engaged the easiest supply chain available to him. Güemes y Horcasitas approved of Montiano's decision, which is telling considering the Cuban governor's zealous support of the guarda costas on his own island. One of the guarda costas sponsored by Güemes y Horcasitas, the Triunfo captained by Domingo López de Avilés, captured ten British vessels in the year 1737 with the spirited support of the governor. ${ }^{62}$ Forced into situations in which the best defense of Spain's American territories meant engaging in foreign commerce, both Güemes y Horcasitas and Montiano acted in similar ways to Mendinueta.

shipping, this study focuses on contraband trade from the metropolitan perspective. For works that approach contraband trade through an analysis of the social stratification, merchant competition, and political factions, see: Cromwell, Jesse Levis. "Covert Commerce: A Social History of Contraband Trade in Venezuela, 1701-1789." PhD diss., University of Texas at Austin, 2012; Prado, Fabrício Pereira, "Colônia do Sacramento: a situaço na fronteira platina no século XVIII," Horizontes Antropológicos, Vol. 9, 1 (2003): 79-104; and Moutoukias, Zacarias, "Power, Corruption, and Commerce: The Making of the Local Administrative Structure in Seventeenth-Century Buenos Aires," Hispanic American Historical Review, Vol. 68, No. 4, (Nov., 1988): 771-801.

${ }^{61}$ Joyce Elizabeth Harmon, Trade and Privateering in Spanish Florida: 1732-1763 (The St. Augustine Historical Society, St. Augustine, Florida, 1969): 21.

${ }^{62}$ Levi Marrero, Cuba: Economía y Sociedad: del monopolio hacia la libertad commercial (1701-1763)(I) (Editorial Playor, Madrid, España 1978): 81. 
In the cases of Güemes y Horcasitas, Montiano, and Mendinueta, engagement in or support of the contraband trade did not imply disloyalty but, rather, pragmatism. The ability of imperial agents to disregard elements of Spanish law, moreover, was legally institutionalized through appealing to the king. Each of these colonial agents invoked the logic of Spanish imperial law that the king, as the ultimate arbiter of justice, would approve of their actions if he were aware of the situation on the ground. ${ }^{63}$ While Mendinueta refrained from detailing his dependence on contraband trade to the king, he made clear that Cartagena lacked fundamental supplies that the British could provide. Mendinueta appealed to King Philip V that without the importation of Jamaican flour "we find it impossible to Continue in Cruising because the Royal Officials [in Cartagena] said there are absolutely no supplies to meet [a maritime force's] most basic Needs. ${ }^{, 64}$ In 1731, moreover, Governor Antonio de Salas hinted at the longstanding supply chains running from Jamaica to Cartagena in a testimony to the crown. According to Salas, "a packetboat named Sara, her captain John Paris arrived from Jamaica carrying Goods and supplies for the Ships of the Guardacostas." Salas testified that the arrival of goods from Jamaica under the commission of one Domingo Justiniani, resident of that island, was quite frequent. ${ }^{65}$ Taking Salas's testimony, it is clear that Mendineuta's lack of supplies was met by the regular arrival of contraband goods from Jamaica. Illicit supply chains provided Mendinueta with the means necessary to accomplish his primary responsibility - provide for the guarda costas and Cartagena's defense.

\footnotetext{
${ }^{63}$ For a discussion of the legal concept of "se acata pero no se cumple," or "I obey but do not comply," see: Moreno, "The Spanish Colonial System: A Functional Approach," p. 317-8.

${ }^{64}$ Archivo General de Indias, Santa Fe 1093, Don Gabriel de Mendinueta, Puerto de Cartagena 16 de febrero, 1729.

${ }_{65}$ Archivo General de Indias, Indiferente General 2809, Testimonio de Cartagena, 18 de diciembre, 1731.
} 


\section{The International Role of the Guarda Costas}

Mendinueta took his post in Cartagena during the tumultuous early decades of the eighteenth century as warfare ended in Europe and a new Spanish dynasty was crowned. The War of Spanish Succession gave Madrid the unprecedented opportunity to centralize authority over the country's semi-autonomous provinces. Further, inheriting the reforming impulses of the reign of Charles II, the new Bourbon monarchy sat poised for greater control over and reform of the Indies trade. Yet, the new king suffered from his own paralyzing personal demons and became dependent on the strong-will and force of character of his second wife, Elizabeth Farnese. ${ }^{66}$ While Farnese brought bright and able ministers into the highest echelons of Spain's government, her single-minded focus on obtaining Italian principalities for her sons hamstrung many initiatives that her ministers considered more important to Spain's imperial health. ${ }^{67}$ One of the highly competent ministers who Farnese brought to Spanish government, José Patiño, took a special interest in foreign trade and Spanish American governance.

Patiño showed a keen interest in the defense of Spain's trade with the American colonies. He rose in the ranks of Spanish bureaucracy partially through his connections with the abbé Alberoni, an association which indebted him greatly to Alberoni's patron, Elizabeth Farnese. ${ }^{68}$ While not a reformer in the sense of the later Bourbon ministers, Patiño instinctively recognized the need for Spain to exert a strong naval presence, especially in the face of British commercial aggressions in the Americas. ${ }^{69}$ Patiño understood the abuses perpetrated by British merchants, insight he gained when he sent

\footnotetext{
${ }^{66}$ For two lively accounts of Philip V's emotional and mental issues, see: John D. Bergamini, The Spanish Bourbons: The History of a Tenacious Dynasty (New York: Putnam, 1974); and Carlos Martínez Shaw and Marína Alfonso Mola, Felipe V (Madrid: Arlanza Ediciones, 2001).

${ }^{67}$ See: John Lynch, Bourbon Spain: 1700 - 1808 (Basil Blackwell, Cambridge, Mass. 1989): pp. 80-95.

${ }^{68}$ John Lynch, Bourbon Spain: 1700-1808 (Basil Blackwell, Cambridge, Mass. 1989): 84.

${ }^{69)}$ Stein and Stein, Silver, Trade, and War, p. 203.
} 
the naval officers with the French scientific expedition of La Condamine to report back to him on the state of the Indies. ${ }^{70}$ Patiño also understood Spain's relatively weak bargaining position coming out of a war with no significant naval power. The administrative rise of Patiño worried some British observers. British ambassador Benjamin Keene lamented, "No one can be more certain than I am, that [Patiño] is an enemy to all foreign commerce, and as he had more knowledge of trade and of the abuses in the customs than any minister had before him, he will make us more uneasy than any has yet done." ${ }^{, 71}$ Farnese's patronage of Patiño, however, forced the minister to reorient his American designs around her Italian concerns, leading to a creative exploitation of American maritime violence for Spanish imperial gain in Italy.

In the decades following the War of the Spanish Succession, Spain had neither the finances nor political will for another continent-wide conflict, despite Farnese's aggressive posturing towards the Italian principalities of Tuscany and Parma. By deploying what one scholar has described as "the diplomacy of menace," Patiño coaxed Britain into the Treaty of Seville in which Britain promised to support Spain's aggressions in Tuscany and Parma by promising to reign in the guarda $\operatorname{costas}^{72}$ The threat of guarda costa violence played into Patiño's diplomatic arsenal because of the asiento contract. ${ }^{73}$ The lucrative trade contract meant that Patiño could push his British counterparts further because a declaration of war would prove costly to Britain. The threat of financial loss allowed Patiño to issue empty decrees in response to British

\footnotetext{
${ }^{70}$ Ibid., p. 203.

${ }^{71}$ Keene to Walpole, November 25, 1731 quoted in Lynch, Bourbon Spain, p. 146.

${ }^{72}$ Lynch, Bourbon Spain, p. 136.

73 The asiento contract was the right to trade a specified number of slaves to Spanish America. The need for the contract began with the Treaty of Tordesillas in 1492 which divided the known world between Spain and Portugal, separating Spain from access to the African coast. From that moment forward, the Spanish empire depended on foreign importers to bring African slave labor to its colonies across the Atlantic. Britain received the contract as a concession following the War of the Spanish Succession.
} 
outrage without enacting concrete plans to curb the violent depredations of the guarda costas. In one such decree from 1732, "Governors are to understand, that they shall be answerable for the Violences which the said Cruizers shall commit. ${ }^{, 74}$ In order to prevent violence and the seizure of unlawful prizes, the decree further recommended that, "before [governors] give them Commission to go to Sea, they ought to examine into the Characters of their Persons." 75 Yet, even Patiño's negotiating counterpart, Benjamin Keene, recognized that placing blame on Spanish American governors for guarda costas seizing unlawful prizes simply added to "la lenteur Espagnole," with little restitution for British American seamen. Beyond adding delays to the process of adjudicating on prizes, Keene recognized "a share of malice" in Patiño's maneuvering, knowing that his wellworn sentiments of outrage at the utter lawlessness of the guarda costas belied little attempt to remedy that maritime violence. ${ }^{76}$

Spain's relative lack of naval power going into the eighteenth century meant that the success of Patiño's policy also depended on the illicit trade. ${ }^{77}$ As the Daily Courant reported in 1726, "Don Joseph Patino is very busy in finding out Ways and Means for raising Money for the present Emergencies." While the minister recognized the need for a more vigorous policing of Spain's American trade, he offered, "a high Interest to the monied Men here to advance Money; but the Securities for Repayment being precarious, and Money very scarce, his Propositions meet with many Difficulties." Patiño's fiscal difficulties were further complicated by the demands of the Intendant of Marine, who needed, "Sixty six thousand Pieces of Eight from the Commerce there, for defraying ...

\footnotetext{
${ }^{74}$ American Weekly Mercury, April 20, 1732, issue 643, p. 3.

${ }^{75}$ American Weekly Mercury, April 20, 1732, issue 643, p. 3.

${ }^{76}$ Keene to Walpole, November 25, 1731 quoted in Lynch, Bourbon Spain, p. 146.

${ }^{77}$ Henry Kamen, Spain, 1469-1714: A Society of Conflict (Harlow, United Kingdom, 2005): 274.
} 
the Charge of two Men of War, which are to go to cruise against the Interlopers upon the Coast of Cartagena." ${ }^{78}$ While the cost of two Men of War strapped Spain's already precarious budget, Patiño would have understood the benefits of allowing privateers to patrol American waters. Avarice drove Spanish American seamen in pursuit of wealthy British prizes, relieving the state of the heavy burden of providing maritime defense. With his knowledge of trade in the Indies, including the illegal aspects of it, Patiño would have recognized that many of the naval stores and supplies which the guarda costas needed would arrive through illicit channels. ${ }^{79}$ Patiño's success, therefore, rested on his ability to use the contraband trade as an instrument of empire. By tapping into British trade networks for supplies, in many ways men like Mendinueta were accomplishing exactly what Patiño wanted. Illegal from the point of view of the Spanish, these trade networks were nonetheless used as supply chains for the nascent Spanish naval presence in the Caribbean.

Despite the rag-tag nature of the Spanish guarda costas fleet, they proved remarkably successful at harassing British American shipping. Although their official mandate remained to protect Spain's American possessions from illicit traders, their actions belied the larger purpose set out for them by Patiño. British governors throughout the Americas lodged complaints similar to that of Governor Archibald Hamilton of Jamaica who wrote the Council of Trade and Plantations that guarda costas robbed British subjects with impunity throughout the Caribbean. According to Hamilton, many

\footnotetext{
${ }^{78}$ Daily Courant (London, England), Thursday, October 27, 1726; Issue 7810, page 2. The "Emergency" which Patiño faced in 1726, specifically involved the blockading of Cartagena by Vice-Admiral Francis Hosier as a result of anger over guarda costa seizures. See: Nowell, Charles E. "The Defense of Cartagena," The Hispanic American Historical Review, Vol. 42, No. 4, 1962.

${ }^{79}$ Juan and Ulloa, Discourse, pp. 45-50; Archivo General de Indias, Santa Fe 374, Letter from José Patiño to the King, April 14, 1722.
} 
British ships were seized "for which no other pretence, has in some cases been found, then that some few Spanish pistolls or inconsiderable sums of coin'd silver . . . has been found on board." Worse still were the cases in which British vessels were seized and held under the mere suspicion of illegal trade. ${ }^{80}$ While claiming that seized British vessels were innocent of engaging in contraband trade may have served as cover for those vessels' restitution, from the perspective of the Spanish political economy, such claims mattered little. If Patiño wished to use the actions of the guarda costas to pressure Britain into supporting his patron's Italian designs, then the ships proved more effective to him the more outrage they incurred among British merchants. Patiño's promises to curtail the cruising of guarda costas in American waters functioned to bring British officials to the negotiating table.

Much ink was spilled in the British American press regarding the violence perpetrated by the guarda costas throughout American waters. Readers of these newspapers encountered many examples of stories such as that which ran in Philadelphia on July 14, 1720. According to the article "18 Dead Bodies, appearing to be English Men, were found, drove on Shore," off the coast of Virginia. The paper reported the bodies to be the victims of a guarda costa commissioned out of St. Augustine. As if the shock of eighteen dead were not enough, the story went on to detail how the victims were "tied back to back," with one gentleman "found with his hands tied behind him, and his two great toes tied together." their drowning when thrown into the Atlantic. Whether or not the unfortunate British subjects encountered a guarda costa or any number of stateless Caribbean pirates remains

\footnotetext{
${ }^{80}$ CSP, 1716 p.203.

${ }^{81}$ American Weekly Mercury, July 14, 1720, issue 30, p. 2.
} 
as inconclusive now as it would have been in 1720 . The newspaper article does, however, demonstrate the kinds of violence which the British considered the guarda costas capable of committing.

While the guarda costas were blamed for some maritime violence with scant evidence, many more cases of bloodshed fell squarely on their shoulders. In 1731, for example, a British Royal Navy vessel, the Spence, "had taken a Spanish Guard la Costa; and on board her found an Englishman newly murdered." 82 In another encounter between the British Navy and the guarda costas, Captain Berkeley of the Windsor came across an English master and two other men in a canoe off the coast of Hispaniola. According to the English master, his vessel was seized by a guarda costa who kidnapped the three men in order to use them as pilots on a privateering cruise up the North American coast. The master claimed that the Spanish seamen of the guarda costa treated the rest of his crew with, "cruelties," such as, "cutting off noses and arms in cold blood and wantonness." While it remains doubtful that Patiño ordered Spanish American officials to condone such bloodshed, the Spanish administration under his watch accomplished little by way of preventing it. The hysteria caused by such tales fed the pressure Patiño needed to place on his British counterparts.

The Royal Navy and the Commercial Proxy War

The violence perpetrated by the guarda costas of Cartagena played well in Patiño's "diplomacy of menace," yet they were also responding to the threatening

\footnotetext{
${ }^{82}$ South Carolina Gazette, March 11, 1731, no. 10; Harmon, Trade and Privateering in Spanish Florida, p. 7.

${ }^{8.3}$ Vernon to Duke of Newcastle and Sir Charles Wager (Draft) [Burford, at Port Royal, August 30, 1740] in Ranft. The Vernon Papers, p. 125.
} 
presence of the British Royal Navy. ${ }^{84}$ A change in British policy in the early decades of the eighteenth century meant that, in many ways, Spanish America went from being under economic invasion to being in very real danger of an actual British siege. As Jamaican Governor Lawes realized in the first days of his tenure in office, interlopers were not the only British vessels plying contraband goods throughout Spanish America. The British Royal Navy entered into the illicit trade throughout the early decades of the eighteenth century, thereby actively pushing for the free trade, blue-water empire that their Whig party backers in London so desperately wanted. ${ }^{85}$ The image of seventy and eighty-gun navy vessels approaching Spanish American port cities to force trade complicates the usual narrative of easy trans-imperial economic relations on the periphery of empire. ${ }^{86}$ The threatening presence of the British Royal Navy in the waters around Cartagena gave heightened importance to the guarda costas as maritime defenders of Spanish American port cities.

Considering the threat of war and the loss of the asiento contract, the participation of the British Royal Navy in illicit trade must be understood within Britain's larger political economy stretching back to the seventeenth century. In much the same way that the War of the Spanish Succession centralized Madrid's authority over its hinterlands, England was also reshaped by its own republican experiment. Described by one scholar as, "an unqualified failure," the reign of Oliver Cromwell proved a boon to the fortunes of England as a maritime power and permanently altered the balance of power in the

\footnotetext{
${ }^{84}$ Lynch, Bourbon Spain, p. 136.

${ }^{85}$ For a more detailed discussion of this debate, see: Steve Pincus, "Rethinking Mercantilism: Political Economy, the British Empire, and the Atlantic World in the Seventeenth and Eighteenth Centuries," in William and Mary Quarterly, 3d ser., 69, no. 1 (Jan. 2012): 3-34.

${ }^{86}$ In much of the historiography, frequency of smuggling and illicit trade is conflated with ease of conducting illicit transactions - a point which the violence surrounding illicit trade around Cartagena should complicate. For examples, see: Cathy Matson, "Imperial Political Economy: An Ideological Debate and Shifting Practices," in William and Mary Quarterly, 3d ser., 69, no. 1 (Jan. 2012), esp. footnote 12.
} 
Caribbean. ${ }^{87}$ In a political era epitomized by fear and aggression, naval strength became a psychological and strategic panacea for England during the middle decades of the seventeenth century. ${ }^{88}$ While building up forces on the island for protection against enemies, real and imagined, Cromwell developed an aggressive plan to developed footholds in the Spanish Caribbean from which to harass his Catholic foes. Cromwell expected his planned invasion of Jamaica to continue in the Elizabethan legacy of war 'beyond the line' but his overtly aggressive policy destroyed amicable relations in the eyes of the Spanish. This hostility set the stage for eighteenth-century conflicts where belligerence in the Americas translated to widespread warfare on the European mainland. ${ }^{89}$ Cromwell's fall eased relations between Spain and Britain but possession of Jamaica and a tradition of aggressive naval actions in the Americas remained a longlasting legacy of the period.

While the return of the monarchy in Britain offered Spanish America a reprieve from the kinds of bellicose actions of the Cromwell regime, British planners still sought access to Spanish America's wealthy resources. The eighteenth century became the era of contraband trade in the Americas as British merchants endeavored to more completely break through Spain's trade monopoly. Yet, British politicians were divided over how best to tap into Spanish American trade wealth, a division which crossed the Atlantic and complicated relations between Britain and Spain over issues of trade. On the one hand, Tory planners developed the South Sea Company as the trading entity responsible for carrying out Britain's asiento contract with Spanish America, thereby seeking access to

\footnotetext{
${ }^{87}$ N.A.M. Rodger, The Command of the Ocean: A Naval History of Britain, 1649-1815 (W.W. Norton \& Company, New York, NY 2004): 32.

${ }^{88}$ Ibid., p. 32.

${ }^{89}$ A.P. Newton, The European Nations in the West Indies 1493-1688. (Adam \& Charles Black, London, 1933), p. 213.
} 
trade through monopolizing the treaty concessions that Britain obtained through the War of the Spanish Succession. ${ }^{90}$ On the other hand, Whigs sought to "pry open Spanish American markets for British manufactures."91 Jamaican interlopers carried out free-trade with Spanish America with the tacit approval of the Whigs, while agents for the South Sea Company railed against the competition with the Company's monopoly privileges. Added to this milieu, the British Royal Navy, largely supported in Parliament by Whigs, aggressively defended Britain's trade with Spanish America - both licit and illicit. ${ }^{92}$

The issue of armed British vessels weighing anchor at Spanish American ports brought to the fore questions of imperial dominance and the very security of Spain's American possessions in ways that Jamaican interlopers never had. While the 1729 Treaty of Seville proved a diplomatic success for Patiño in gaining British support for the seizures of Tuscany and Parma, part of the treaty betrayed the heart of Spanish fears regarding armed British navy ships engaging in trade in the Americas. According to the treaty, Britain agreed to "prohibit and effectively bar under any pretext ships of war of his British Majesty from sheltering, escorting, or protecting the embarkations that commit illicit commerce on the coasts of the dominions of his Catholic Majesty."93 Yet, just as Patiño used the threat of guarda costa violence for diplomatic gain despite promises made in the Treaty of Seville, the participation of the British Royal Navy in contraband trade supported the political will of the Whigs in Parliament despite their own promises to terminate the trade. For the Spanish, the British policy of forcing open trade in Spanish America with ships of the line as a wedge struck a deeper chord than the arrival of illicit

\footnotetext{
${ }^{90}$ For a more detailed discussion of Tory's role in the formation of the South Sea Company, see, Pincus, "Rethinking Mercantilism."

"1) Pincus, "Rethinking Mercantilism," p. 27.

'2 See, Rodger, The Command of the Ocean, pp. 178-185.

${ }^{93}$ El Tratado de Sevilla (1729) quoted in Marrero, Cuba: Economía y Sociedad, p. 81. Translation is my own.
} 
bolts of Brittany linen or barrels of North American wheat. For Patiño and Spanish American officials such as Mendinueta, the British Royal Navy turned the tables in the proxy war waging in the Caribbean.

The Royal Navy's primary responsibility in American waters was to restore Britain's maritime prestige which had suffered by the seizures of British vessels by the guarda costas. For an empire which prided itself on the extent of its trade and naval power, Patiño's policy hurt the British where it counted the most by curtailing their freedom of navigation. According to an editorial in the London Magazine and reprinted throughout North America, "it is impossible that the British Commerce can be safe in any Part of the World where it can be interrupted by a Spanish Cruiser, or Guarda Costa," because, as the commentator noted, the Spanish, "seize every English Ship they can make themselves Masters of." 94 The danger of guarda costa attack, moreover, extended beyond the British Empire's merchant vessels. In one case off the coast of Cuba, the sloop Hannah and Lydia, captained by Edward Sunderland, was seized by a Puerto Rican guarda costa. Beyond taking the vessel and its valuables, the passengers aboard the sloop were reportedly beaten and abused at the hands of their Spanish captors. ${ }^{95}$ British subjects expressed their outrage at their curtailed liberties as some members of Parliament agitated for war.

Before the outbreak of the War of Jenkins' Ear, however, both the Whigs and the British Navy faced constraints with how far they could push back on the Spanish empire. ${ }^{96}$ The diplomatic maneuvers that allowed Patiño to promise to reign in the

\footnotetext{
${ }^{94}$ South Carolina Gazette, Thursday, June 22, 1738, no. 230.

${ }^{45}$ South Carolina Gazette, September 23, 1732, no. 36.

"ST, Colin Palmer. Human Cargoes: The British Slave Trade to Spanish America, 1700-1739 (University of Illinois Press, 1981).
} 
guarda costas while simultaneously encouraging their actions paralleled the efforts of the British to maintain peace at the very edge of war. While the South Sea Company still held the asiento contract, and the British public remained heavily invested in the Company's stock, outright war proved impracticable. Within such limitations, however, the British Royal Navy carved a niche in the smuggling trade to Spanish America by using force or the threat thereof for economic gain. For British imperial planners, the role of the Navy supported their commercial interests in the Americas. For Jamaican officials, however, the Navy's extracurricular activities in the Caribbean left the port and the island's merchants open to pirate and guarda costa attacks.

Perhaps just as prejudicial to Jamaica, however, was the competition offered by the Royal Navy to the island's lucrative interloping trade. According to Governor Lord A. Hamilton, Jamaican merchants as early as 1712, "Complain of the discouragement of their trade, particularly of the most considerable and advantageous branch of it, that to the Spanish coast, through Commanders of H.M. ships of war having in great measure engrost it and carrying it on with the Queen's ships." Rather than argue that the Royal Navy's extra-legal trade interfered with their ability to protect the island, Hamilton went on to argue that the ships of the Royal Navy engaged in commerce with Spanish America, "to the discouragement of that of the merchants," of Jamaica. ${ }^{97}$ Hamilton's later successor, Governor Lawes, echoed a similar complaint about the Navy's trading activities along with his protests about the state of the island's security. According to Lawes, the Royal Navy carried merchandise to Spanish America "which otherwise would be done by vessells belonging to the Island, and consequently be a livelihood to numbers of seafaring men, who now have not bread for want of employment, which is the chief

\footnotetext{
${ }^{97}$ CSP 1712-1714, p. 123.
} 
occasion of so many of them going a pyrating. $" 98$ In Lawes' calculations, not only did the Royal Navy neglect their duty to protect Jamaican shipping, but by cutting into the interloping trade, the Navy further harmed the island by forcing its unemployed seamen into piracy. Caught between the crosshairs of these competing commercial interests were the port cities of Spain's American empire.

Similar to Patiño's manipulation of the contraband trade for the good of Spanish imperial policy, the Royal Navy's engagement in illicit trade served as a tool of empire which benefitted Kingston as much as London, despite complaints from Jamaican officials. Smuggling by the Royal Navy reflected a wider British political philosophy regarding free trade and open navigation of the world's oceans, a philosophy which Jamaican interlopers themselves embraced. The point was an old one, argued effectively by the Dutch jurist Hugo Grotius, that the Atlantic was a mare liberum despite Spain's claims to dominion. According to Grotius, non-Iberian powers had no duty to respect Spain's claim to a mare clausem Atlantic in which trade and possession remained in the hands of the "discoverers" in perpetuity. Taking Grotius's seventeenth-century argument further, the British Empire of the eighteenth century wanted much more than just the ability to navigate the Atlantic, they wanted to right to ply their manufactured goods at any port in that mare liberum. ${ }^{99}$ The British Royal Navy brought the benefit of superior arms to force such trade on Spanish America, benefitting all British subjects with an interest in transimperial trade.

\footnotetext{
${ }^{18}$ CSP, no. 272 (1717-18): 271.

${ }^{99}$ For more on this, see: Anne Perótin-Dumon, "The pirate and the emperor: power and the law on the seas, 1450-1850," in James D. Tracy, ed., The Political Economy of Merchant Empires: State Power and World Trade, 1350-1750 (Cambridge University Press, 1997); and Lauren A. Benton, A Search for Sovereignty: Law and Geography in European Empires, 1400-1900 (Cambridge University Press, 2010).
} 
While the South Sea Company engaged in the asiento contract in the hope of amassing wealth through access to Spanish American ports, such desires were largely unattainable. The monopoly privileges of the Company also meant that Company traders ostensibly operated within the confines of the law, unable to engage in the more profitable free-trade of Jamaican interlopers. ${ }^{100}$ In response to these confines, British negotiators sought and received permission for a license vessel of first 500, later 1,000, tons to trade to Spanish America in synch with the annual Spanish trade fairs. ${ }^{101}$ In the long run, however, the Kingston interlopers would far eclipse the South Sea Company in supplying the Spanish Main with much-needed trade goods. ${ }^{102}$ The decline in the profitability of the asiento contract for the South Sea Company in the years before the outbreak of the War of Jenkins' Ear coincided with a Whig-dominated political desire for free trade in the Americas. Violence perpetrated against British mariners further added to the calls for war against Spain, now seen worth the risk of losing the unprofitable asiento contract.

The goal of attaining free trade in the Americas at the expense of the Spanish monopoly was embraced by the Royal Navy's leading commander in the Caribbean during the War of Jenkins' Ear. Following his successful attack on Porto Bello in November of 1739 , Vernon wrote back to Sir Charles Wager to extoll his accomplishment - the opening of a Spanish American port to British trade. According to Vernon, Porto Bello served as one of, "the principal mart[s] for our merchants," who exchanged manufactured goods for bullion in the years, "before the establishing a South

\footnotetext{
${ }^{100}$ See: Curtis Nettels, "England and the Spanish-American Trade, 1680-1715," Journal of Modern History , Vol. 3, No. 1 (Mar., 1931), pp. 1-32.

${ }^{101}$ Nettels, "England and the Spanish-American Trade," p. 31.

${ }^{102}$ Palmer, Human Cargoes, pp. 158.
} 
Sea Company interrupted the private trade." ${ }^{103}$ A devotee to the notion of free trade, Vernon appeared little concerned with the damage that interloping caused the South Sea Company, despite the British Company's monopoly on trade with Spanish America. Vernon considered his principal task in Porto Bello to, "lay a solid foundation of intercourse between our merchants and them, to recover so beneficial a trade to the nation," which he was able to argue had been a "success under my protection."104 Smuggling, rather than trading companies, embodied the Whig ideal upheld by men like Vernon. In such a philosophy, the nation grew strong through the trade of manufactured goods which were shipped by British vessels, thereby strengthening the Navy, and bought with foreign bullion, thereby accruing wealth while weakening the enemy. The South Sea Company, however, interrupted a flourishing trade in Porto Bello which Vernon stated that he could, "remember flourishing here above thirty years ago," and that he was able to reassert by forcefully opening the port to interlopers. ${ }^{105}$

The popular celebrations which followed Vernon's success at Porto Bello epitomized the wider British sense of entitlement to free trade in the Americas. While imperial planners in Britain recognized the truth in Lord Haversham's argument that trade and naval strength "both together are the wealth, strength, security and glory of Britain," the early decades of the eighteenth century witnessed a popular enthusiasm for maritime dominance. Much of this attention stemmed from the vociferous outcry of merchants and their supporters in the press regarding guarda costa attacks. According to historian Kathleen Wilson, daily conversations in Britain revolved around trade and the

\footnotetext{
${ }^{103}$ Vernon to Sir Charles Wager [Strafford, in Porto Bello Harbour, April 5, 1740] in B. McL. Ranft, ed. The Vernon Papers (Navy Records Society, London, England 1958): 86.

${ }^{104}$ Vernon to Sir Charles Wager [Strafford, in Porto Bello Harbour, April 5, 1740] in B. McL. Ranft, ed. The Vernon Papers (Navy Records Society, London, England 1958): 86.

${ }^{105}$ Vernon to the Secretary of the Admiralty (Draft) [Burford, at Port Royal, May 26-31, 1740] in Ranft, The Vernon Papers, p. 311.
} 
guarda costas as the people and Parliament agitated for revenge on the Spanish Empire. ${ }^{106}$ The lines, "Tame proud Iberia, shake ye Gallick throne, Give freedom to the World, and keep her own," from A Skit on Britain reflect such popular sentiment. For Londoners, the British press, and Navy, free trade in the Americas became an issue far more important than sheer economics. ${ }^{107}$ Rather, mare liberum in terms of navigation and trade came to symbolize the very freedom and survival of the British Empire. In this sense, Vernon fought for much more than just new markets for British manufactures during the War of Jenkins' Ear.

Despite the pomp and rhetoric about the importance of His Majesty's navy and its very real role in defending British merchants from guarda costas harassment, men like Edward Vernon found themselves undersupplied for their American deployments. Just as Mendinueta received orders which he could not fulfill without engaging in foreign commerce, Vernon relied on smuggling and prize money to fill in the gaps in supply from his superiors. In one such instance, Vernon requested, "bay frocks and trousers as very proper for [the Caribbean] in the rainy seasons," for his crew who experienced extreme cold on night watch without them. Despite repeated inquiries regarding the clothing, Vernon was only able to provide his men with the frocks and trousers by securing extranaval money to outfit his crew. With an average five percent fee charged to smugglers for convoying their vessels or their goods, securing the funds himself proved far easier than getting supplies through the regular channels. ${ }^{108}$

\footnotetext{
${ }^{106}$ Kathleen Wilson, The Sense of the People: Politics, Culture and Imperialism in England, 1715-1785 (New York 1995): 50.

${ }^{107}$ Ibid., p. 137.

${ }^{108}$ Rodger, The Command of the Ocean, p. 234.
} 
While carrying extralegal goods defied the wishes of the Admiralty Board and opened British American ports up to foreign aggression, the trade was essential for the maintenance of His Majesty's ships in American waters. For Vernon, as for Mendinueta, one of the primary concerns was receiving enough food to keep his men at sea. The main ordinance store for the British Navy in the Caribbean was on the tropical island of Jamaica, which meant that the majority of the foodstuffs needed by the Navy arrived through North American trade channels. Yet, as Vernon complained to the Victualling Board, "I am greatly apprehensive if they depend on [North American trade], his Majesty's Forces will run the hazard of starving here." For, despite the bellicose language of British North American merchants who complained of guarda costa attacks, Vernon stated that those same merchants preferred to trade with possessions of the Spanish and French crowns because the merchants received, "their payments from them either in money, or commodities [and] they can get at lower prices." 109 Some of the most basic needs of the British Royal Navy - food and clothing - were met by the contraband trade, despite clear regulations from the Admiralty Board prohibiting naval ships from carrying on such commerce.

For both Mendinueta and Vernon, providing adequately for their crews proved even more important considering the competition prevalent in the eighteenth-century Caribbean for competent seamen. Not only did men of the sea have their choice between interlopers, privateers, and merchantmen of their own empire, but the maritime world proved highly permeable between empires. As in the famous case of Edward Coxere, who served on Spanish, Dutch, British, and Turkish ships before being taken prisoner by

${ }^{109}$ Vernon to the Victualling Board (Draft) [Burford, at Sea, October 4, 1740] in Ranft. The Vernon Papers, p. 361 . 
the Spanish, imperial subjecthood mattered little in the open blue waters of the world's oceans. ${ }^{110}$ Even Vernon complained of the "shock one to think there can be wretches as abandon'd as even to desert the service of God, as well as the Crown and their country, by going over to the enemies of our holy religion," during the early stages of the War of Jenkins' Ear. For Vernon, these seamen's, “ingratitude is the more shameless, as a principal view of this war, has been to secure our seamen from being prey to Spanish Guarda Costas." And yet, instead of the prescribed capital punishment for such desertion, Vernon granted the recalcitrant seamen a general pardon if they returned to their British vessels. ${ }^{111}$ Vernon was not displaying uncharacteristic leniency by granting deserting sailors a pardon but, rather, a pragmatic outlook in response to the constant competition and wide market available to seamen.

While impressments filled the British Navy's rosters, it remained up to individual commanders to keep those men when the ships weighed anchor at various ports. Perhaps for this reason, Captain Christopher O'Brien argued that, "It is [the captain's] indispensible duty to see that the poor seamen be not wronged of his due, nor the service carried on by noise, stripes or blows," and "not the ship made the prison of, but where the service requires immediate and constant attendance." 112 For men like Vernon, "immediate and constant attendance" was mandatory to retain enough men to put ships out each season. Despite the technical illegality of British Navy ships carrying contraband trade, the minor transgression meant that Vernon supplied his men and kept navy operations in the Caribbean running smoothly. While Vernon was a professed

\footnotetext{
${ }^{110}$ Rodger, The Command of the Ocean, p. 61.

111 Order to Sir Chaloner Ogle and Commodore Lestock [Princess Carolina, off Cartagena, March 7 , 1740/1] in Ranft, The Vernon Papers, p. 426.

${ }^{112}$ Quoted in Rodger, The Command of the Ocean, p. 321.
} 
advocate for free trade, what the Spanish deemed contraband trade, he was also as dependent on that trade as his Spanish counterpart at Cartagena. Both Vernon and Mendinueta competed for available seamen, thereby increasing their dependence on contraband trade in order to provide their maritime crews with supplies.

With the participation of the British Royal Navy in the contraband trade to Spanish America, violence in the years leading up to the War of Jenkins' Ear escalated out of control. While the guarda costa fleets sailed with instructions to disrupt British American shipping, they encountered more than just unarmed merchantmen. Nor were Spanish American settlements free from harassment by their British counterparts. In 1715, the governor of Cuba complained to Governor Hamilton of Jamaica that several vessels had been fitted out from that island and that, "some of them had landed near Havana and committed hostilities on the ships and dominions of the King of Spain." 113 Even Rear Admiral Charles Stewart admitted that many of the British seamen who complained about the depredations of the guarda costas were themselves guilty of illicit trade and barbarity in Spain's American possessions. ${ }^{114}$ Perhaps the greatest danger for Spanish seamen seeking out British prizes came when they encountered not prizes, but vessels of the Royal Navy. Such was the case when Captain William Laws sailed the Drake through the Windward Passage on a voyage to London. En route, the vessel was, "attack'd by a Spanish Privateer, who took her for a Merchantman." The mistake proved costly to the unfortunate guarda costa when the Drake returned fire and sunk the other ship, killing all those on board. ${ }^{115}$

${ }_{113}^{113}$ CSP. 1716, no. 158

${ }_{115}^{114}$ Harmon, Trade and Privateering in Spanish Florida, p. 7.

${ }^{115}$ Boston Evening-Post, October 29, 1739, issue 221, p. 1. 
While British crews faced abuse, torture, and even death at the hands of guarda costas, some Spanish American seamen risked a fate worse than each of those. While many of the eighteenth-century's seamen were mixed-race, men of African descent onboard guarda costas faced enslavement at the hands of their British captors. After a Spanish American seaman by the name of Juan Casado Valdés reported being imprisoned by a Jamaican privateer who attempted to sell him into slavery, the governor of Cuba, Alonso de Arcos Moreno, wrote the Council of the Indies. According to Moreno, the widespread British practice of enslaving mixed-race Spanish American seaman, "will be the cause of the end of [Spanish] privateering on these coasts, with the fear which has gripped the free blacks and mulattos of falling into slavery."116 For those free seamen of mixed ancestry, encounters with British American mariners became struggles to maintain their freedom and avoid enslavement on British soil. As a waystation for the transatlantic slave trade, moreover, Jamaican markets sat poised to absorb men like Valdés. Such fears comingled with the general British hysteria over the barbarity of the guarda costas, sparking vicious battles when ships of the two empires encountered one another on the high seas.

\section{The Siege of Cartagena}

Violence over the political economy of smuggling in the Caribbean came to a head with the British invasion of Cartagena. The escalation of forces on either side of the Caribbean increased pressure on already strained sources of supply for both Vernon and Spanish Naval Admiral Blas de Lezo. In a letter from Lezo and intercepted by Vernon,

\footnotetext{
${ }^{116}$ Marrero, Cuba: Economía y Sociedad, p. 35. Translation is my own.
} 
the Spanish commander demanded "a speedy supply of above three hundred thousand quintals of beef, pork and dry provisions, and seventeen hundred barrels of flour," from the French governor of Léogane, L'Arnage. The order indicated to Vernon that, "it is plain [Lezo] is greatly distressed for provisions." 117 Yet, the free trade that Vernon and his supporters encouraged in the Caribbean before the outbreak of the war proved detrimental when the conflict got underway. For, even as Vernon celebrated Lezo's lack of supplies, he published orders in North American newspapers commanding the cessation of the provisions trade to Spanish America. The New-York Weekly Journal, among others, approved of the measure and printed, "The Prohibition for Exporting of Provisions, to any foreign Parts is well received among the People here, it being Judg'd a most effectual way of distressing our Enemies who are in great Want thereof, and without which their Fleets will be unable to put to Sea." ${ }^{118}$ Despite the seemingly unanimous agreement with Vernon's order, however, Cartagena stocked its garrisons in anticipation of the siege with provisions from British American interlopers. ${ }^{119}$

In hindsight, the siege of Cartagena appears an odd choice for a major British Navy operation. Within the larger political economy of the Spanish Empire, the port city of Cartagena proved important because it possessed a very secure harbor for anchoring the treasure fleets. British imperial planners were familiar with the formidable geography and architecture of Cartagena both because of previous naval operations and the fact that Cartagena served as a base for the South Sea Company. The success of Cartagena's guarda costas pointed to a more vigorous imperial presence in the region and should

\footnotetext{
117 Vernon to Governor Trelawny of Jamaica (Draft) [Burford, at Port Royal, November 29. 1740] in Ranft, The Vernon Papers, p. 146.

${ }^{118}$ New-York Weekly Journal, January 26, 1740, issue 373, p. 3.

${ }^{119}$ Lance Grahn. The Political Economy of Smuggling: Regional Economies in Early Bourbon New Granada (Westview Press, Oxford, 1997), p. 176.
} 
have given Vernon and his superiors second thoughts about their proposed invasion. Yet, just as eighteenth-century observers lamented the supposed venality of Spanish American contraband trade, many only saw decay when they looked at Cartagena. Assumptions of corruption, vice, and disloyalty among Spanish American officials, "portend[ed] a fatal revolution," in the years leading up to Vernon's amphibious assault, leading British troops to rush headlong into a foolhardy mission on the Spanish Main. ${ }^{120}$

Despite Vernon's numerical superiority and Cartagena's supposed weakness, the invasion proved to be an unmitigated failure for the British. The troops and fleet arranged to rendezvous on the island of Jamaica before proceeding on to the assault of Cartagena. For many of the troops, however, their hiatus in Jamaica proved disastrous and many succumbed to fever or sickened themselves on the island's plentiful supply of rum. ${ }^{121}$ The disease environment of tropical Cartagena was no improvement over that of Jamaica and was compounded by the mismanagement of such a large force on the part of Vernon and Brigadier General Thomas Wentworth. Perhaps more damaging to Vernon's assault, however, was the robust and brilliant defense put up by the city's soldiers and inhabitants. Focusing their forces on the defense of St. Lazar, the Spanish defenders of Cartagena sunk their own ships in the harbor to keep Vernon from positioning his ships close enough to provide cover for British ground forces. The British were further lulled into complacency regarding the invasion when they handily took Boca Chica Castle and St. Joseph's Fort, finding, "only three drunken Spaniards," at the latter. ${ }^{122}$ The same would not be true of St. Lazar. There, rather than fleeing to the British banner,

\footnotetext{
120) John Lynch, Bourbon Spain: 1700-1808 (Basil Blackwell, Cambridge, Mass. 1989): 59.

${ }^{121}$ Ibid., p.487.

${ }^{122}$ Vernon to the Duke of Newcastle and Sir Charles Wager (Draft) Princess Carolina, in Cartagena Harbour, April 1741, in Ranft, The Vernon Papers, p. 211.
} 
Cartagena's defenders fought their last stand to repulse the invaders. Too late to save the lives of hundreds of invaders, Vernon would come to understand where the residents of Cartagena's loyalties lay.

Yet, Vernon's painful lesson seems lost in much of the scholarship on contraband trade and the War of Jenkins' Ear. Throughout the eighteenth century, as argued by scholar Richard Pares, Spanish American officials in places like Cartagena used the excuse of British violence to explain the rampant contraband trade in their dominions. For historians looking in, commercial violence proved little more than, "expiatory ritual," to mask complicity and venality from metropolitan eyes. ${ }^{123}$ Without a doubt, some Spanish American officials covered their own participation in the smuggling for personal profit. ${ }^{124}$ However, sweeping condemnation of men like Mendinueta distorts the wider Spanish political economy in which they were forced to operate. Moreover, seeing violence as a mere pretext for illicit trade brushes aside the very real bloodshed which became normative in the early decades of the eighteenth century. Worse, blindness to the ways in which illicit or extralegal trade was used by Spanish imperial actors has led to a misinterpretation, both then and now, of the siege of Cartagena and the port's successful defense.

Violent encounters between guarda costas and British American seamen in the circum-Caribbean illuminate the ways in which contraband trade served as a tool of Britain and Spain's trans-imperial political economy. Rather than seeing illicit trade between subjects of disparate empires as a clandestine but unavoidable evil, the

\footnotetext{
${ }^{123}$ Richard Pares, War and Trade in the West Indies, 1739-1763 (London 1963): 6.

${ }^{124}$ The most famous example of this is Viceroy Jorge de Villalonga, who used his position as Viecroy of New Granada to enrich himself. See: Lance Grahn. The Political Economy of Smuggling: Regional Economies in Early Bourbon New Granada (Westview Press, Oxford, 1997); Archivo General de Indias. Escribanía de Cámara 1194, Sentencías del Consejo, Sentencia de Jorge de Villalonga, Virrey de Santa Fe, 1730.
} 
smuggling activities of Mendinueta and Vernon point to the ways in which illegal interimperial trade could serve the purposes of metropolitan planners. Mendinueta supplied the guarda costas with illicit wheat in order to defend the strategically important port of Cartagena. Furthermore, Mendinueta's guarda costas accomplished the broader task of harassing British shipping which allowed Patiño to successfully push his patron's Italian designs at the negotiating table. The British Royal Navy entered the Atlantic in part as a response to guarda costa harassment of British shipping. Yet, naval commanders like Vernon remained too undersupplied to maintain well-fed and, even more importantly, well-paid crews in the competitive eighteenth-century maritime world. Carrying contraband trade in vessels of his royal Majesty bridged supply gaps and moved forward British free-trade designs in Spanish American port cities. Rather than venal officials operating for their personal enrichment, both Mendinueta and Vernon utilized the contraband trade as an instrument of empire while simultaneously producing the need for more smuggling and eventual conflict.

The War of Jenkins' Ear ended Britain's possession of the asiento contract and led to the financial collapse of the South Sea Company, bringing about an economic and political scandal that reverberated throughout Britain. The conflict was subsumed in the near-global outbreak of the War of the Austrian Succession that waged for another decade. Despite war and in the return of peace, Cartagena remained reliant on transimperial trade connections from throughout the Caribbean basin. The commercial ties between Cartagena and Jamaica continued in the later decades of the eighteenth century, slowing only when the American Revolution cut Jamaica off from its former supply of foodstuffs and as the island's sugar production eclipsed all other economic activity in the 
wake of the Haitian Revolution. The world of Caribbean contraband trade cannot be easily separated from the political machinations of imperial planners. Illicit economic relations could and were used in order to enact violence upon or wage war against the very sources of those supplies. War and violence in the eighteenth-century Caribbean meshed imperceptibly with illicit commerce and smuggling. As Vernon discovered, smuggling and imperial loyalty coexisted without contradiction on the peripheries of empire. 
Bibliography

\section{Archival Sources}

Archivo General de Indias

Contraduria. Legajos, 266, 267, 268, 368, 1880.

Indiferente General. Legajos, 2808, 2809.

Santa Fe. Legajos, 1233, 1093, 374.

Museo Naval de Madrid

Legajos. Signaturas, 4388, 14502BMN

\section{Printed Documents and Secondary Sources}

Great Britain, Public Record Office, Calendar of State Papers, Colonial no. 97 (1696-1697).

A Collection of the Parliamentary Debates in England, from the year M,DD, LX VIII To the present time, vol. 16 (London, 1735).

Armesto, Felipe-Fernández. The Americas: A Hemispheric History. New York: Modern Library Edition, 2003.

Armitage, David and Braddick, Michael J. eds. The British Atlantic World, 15001800. New York: Palgrave Macmillan, 2002.

Becerra, Francisco Javier Membrillo .La Batalla de Cartagena de Indias. Madrid: Publidisa, 2011.

Benton, Lauren A. A Search for Sovereignty: Law and Geography in European Empires, 1400-1900. Cambridge: Cambridge University Press, 2010.

Bergamini, John D. The Spanish Bourbons: The History of a Tenacious Dynasty. New York: Putnam, 1974.

Brown, Vera Lee. "The South Sea Company and Contraband Trade." The American Historical Review, 31, no. 4 (1926): 662-678. 
Campillo y Cossío, José del. Nuevo sistema de gobierno económica para la américa. Merida: Universidad de los Andes, Venezuela, 1971, 1789.

Cañeque, Alejandro. The King's Living Image: The Culture and Politics of Viceregal Power in Colonial Mexico. New York: Routledge, 2004.

Colmenares, Germán, "La Formación de la Economía Colonial." in Historia Económica de Colombia, edited by José Antonio Ocampo, Mexico City: Siglo Veintiuno Editores, 1987.

Cromwell, Jesse Levis. "Covert Commerce: A Social History of Contraband Trade in Venezuela, 1701-1789." PhD diss., University of Texas at Austin, 2012.

Davenport, Frances Gardiner, ed. European Treaties Bearing on the History of the United States and its Dependencies. Washington D.C.: Carnegie Institute of Washington, 1934.

Donnan, Elizabeth. Documents Illustrative of the History of the Slave Trade to America. Washington D.C.: Carnegie Institute of Washington, 1931.

Elliott, J.H. Empires of the Atlantic World: Britain and Spain in America, 1492-1830. New Haven and London: Yale University Press, 2006.

Feliciano Ramos, Héctor R. El Contrabando inglés en el Caribe y el Golfo de México, 1748-1778. Sevilla: Diputación Provincial de Sevilla 1990.

Fisher, John R., Kuethe, Allan J., and McFarlane, Anthony, eds. Reform and Insurrection in Bourbon New Granada and Peru. Baton Rouge and London: Louisiana State University Press, 1990.

García, Luis Navarro. Historia General de España y América: Tomo XI-1, Segunda Edición. Madrid: Ediciones Rialp, S.A., 1981.

Giraldo Jaramillo, Gabriel. Relaciones de Mando de los Virreyes de la Nueva Granada Bogotá : Publicaciones del Banco de la República, Colombia, 1954.

Grahn, Lance. Political Economy of Smuggling: Regional Information Economies in Early Bourbon New Granada. Boulder and Oxford: Westview Press, 1997.

Harding, Clarence Henry. Trade and Navigation Between Spain and the Indies in the Time of the Hapsburgs. Cambridge: Harvard University Press, 1918. 
Harding, Richard. Amphibious Warfare in the Eighteenth Century: The British Expedition to the West Indies 1740-1742. Suffolk: Boydell Press, 1991.

Harmon, Joyce Elizabeth. Trade and Privateering in Spanish Florida: 1732-1763. St. Augustine: The St. Augustine Historical Society, 1969.

Jameson, Franklin J. ed., Privateering and Piracy in the Colonial Period: Illustrative Documents. New York: Macmillan Company, 1923.

Jorge Juan, and Ulloa, Antonio de. Discourse and Political Reflections on the Kingdoms of Peru. Oklahoma: University of Oklahoma Press, 1978.

Noticias Secretas De America. London: R. Taylor, 1826.

A Voyage to South America London: R. Taylor, 1772.

Julián, Antonio. La Perla de la América, Provincia de Santa Marta. Bogotá: Academia Colombiana de Historia, 1980.

Kamen, Henry. Spain, 1469-1714: A Society of Conflict. Harlow: United Kingdom, 2005 .

Lane, Kris E. Pillaging the Empire: Piracy in the Americas: 1500-1750. New York and London: M.E. Sharpe, Inc., 1998.

Lawson, Edward W. "What Became of the Man Who Cut Off Jenkins' Ear?" The Florida Historical Quarterly, 37, no. 1 (1958): 33-41.

Liss, Peggy K. Atlantic Empires: The Network of Trade and Revolution, 1713-1826. Baltimore and London: Johns Hopkins University Press, 1983.

Lynch, John. Bourbon Spain: 1700-1808 Cambridge: Basil Blackwell, 1989.

Mapp, Paul W. The Elusive West and the Contest for Empire, 1713-1763. Chapel Hill: University of North Carolina Press, 2011.

Marrero, Levi. Cuba: Economía y Sociedad: del monopolio hacia la libertad commercial (1701-1763)(I). Madrid: Editorial Playor, 1978.

Matson, Cathy. "Imperial Political Economy: An Ideological Debate and Shifting Practices," in William and Mary Quarterly, 3d ser., 69, no. 1 (Jan. 2012).

McFarlane, Anthony. Colombia Before Independence: Economy, Society, and Politics Under Bourbon Rule. Cambridge: Cambridge University Press, 1993. 
Moreno, Antonia Arellano. Documentos para la Historia Económica en la Epoca Colonial, Viajes e Informes. Caracas: Fuentes Para la Historia Colonial de Venezuela, 1970.

Moreno, Frank Jay. "The Spanish Colonial System: A Functional Approach," Western Political Quarterly, Vol. 20, N. 2, (Jun. 1967) 308-320.

Moutoukias, Zacarías. "Power, Corruption, and Commerce: The Making of Local Administrative Structure in Seventeenth-Century Buenos Aires," Hispanic American Historical Review, Vol. 68, No. 4, (Nov., 1988).

Nettels, Curtis. "England and the Spanish American Trade, 1680-1715." The Journal of Modern History, 3, no. 1 (1931): 1-32.

The Money Supply of the American Colonies before 1720. Clifton: A.M. Kelley 1973.

Nowell, Charles E. "The Defense of Cartagena." The Hispanic American Historical Review, 42, no. 4 (1962): 477-501.

Ocampo, José Antonio, ed. Historia Económica de Colombia. Mexico City: Siglo Veintiuno Editores, 1987.

Pagden, Anthony. Lords of All the World: Ideologies of Empire in Spain, Britain and France c.1500-c.1800. New Haven and London: Yale University Press, 1995.

Palmer, Colin. Human Cargoes: The British Slave Trade to Spanish America, $1700-$ 1739. Chicago and London: University of Illinois Press, 1981.

Pares, Richard. War and Trade in the West Indies, 1739-1763. London and Edinburgh: Thomas Nelson Printers, Ltd., 1963.

Perótin-Dumon, Anne. "The pirate and the emperor: power and the law on the seas, 1450-1850," in James D. Tracy, ed., The Political Economy of Merchant Empires: State Power and World Trade, 1350-1750. Cambridge: Cambridge University Press, 1997.

Pincus, Steve. "Rethinking Mercantilism: Political Economy, the British Empire, and the Atlantic World in the Seventeenth and Eighteenth Centuries," in William and Mary Quarterly, 3d ser., 69, no. 1 (Jan. 2012). 
Prado, Fabrício Pereira, "Colônia do Sacramento: a situaço na fronteira platina no século XVIII," Horizontes Antropológicos, Vol. 9, 1 (2003): 79-104.

Rodger, N.A.M. The Command of the Ocean: A Naval History of Britain, 1649-1815. New York: W.W. Norton \& Company, 2004.

Silvestre, Francisco. Descripción del Reyno de Santa Fe de Bogotá. Bogotá: Biblioteca Popular de Cultura Colombiana, 1950.

Stein. Stanley J. and Stein. Barbara H. Silver. Trade, and War: Spain and America in the Making of Early Modern Europe. Baltimore: Johns Hopkins University Press. 2000.

Swanson, Carl E. Predators and Prizes: American Privateering and Imperial Warfare, 1739-1748. Columbia: University of South Carolina Press, 1991.

Temperly, Harold V.W. "The Causes of the War of Jenkins' Ear, 1739." Transactions of the Royal Historical Society, 3, Vol. 3, (1909): 197-236.

Wilson, Kathleen. The Sense of the People: Politics, Culture and Imperialism in England, 1715-1785. New York: 1995.

Zapatero, Juan Manuel. Historia de las Fortalezas de Santa Marta y Estudio Asesor para su Restauración. Bogotá: Academia Colombiana de Historia, 1980. 